\title{
GLOBAL CLIMATE CHANGE AND INTERNATIONAL SECURITY
}

Report on a Conference Held at Argonne National Laboratory

May 8-10, 1991

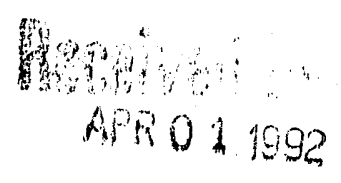

Sponsored by

Midwest Consortium for International Security Studies and Argonne National Laboratory 


\title{
GLOBAL CLIMATE CHANGE AND INTERNATIONAL SECURITY
}

\author{
Report on a Conference \\ Held at \\ Argonne National Laboratory \\ May 8-10, 1991
}

Report Prepared by

Dr. Marian Rice

\author{
Conference Cosponsored by \\ Midwest Consortium for International Security Studies \\ and \\ Argonne National Laboratory*
}

Members of MCISS:

\begin{abstract}
Argonne National Laboratory
Chicago Council on Foreign Relations

Indiana University

Michigan State University

Northwesterı University

Ohio State University

Purdue University

Syracuse University
\end{abstract}

University of Chicago

University of Illinois

University of Iowa

University of 'Kansas

University of Michigan

University of Minnesota

University of Notre Dame

University of Pittsburgh

University of Wisconsin

*Participation by Argonne National Laboratory supported by the University of Chicago Board of Governors for Argonne National Laboratory and by the U.S. Department of Energy. Opinions expressed in this document are those of conference participants and do not necessarily reflect the views of sponsoring organizations. 


\section{Contents}

Introduction $\ldots \ldots \ldots \ldots \ldots \ldots \ldots \ldots \ldots \ldots \ldots \ldots \ldots \ldots \ldots \ldots \ldots$

I Predicting Climate Change: Certainties and Uncertainties of Physical Models . . . . 2

II Implications for Agricultural Production $\ldots \ldots \ldots \ldots \ldots \ldots \ldots \ldots \ldots \ldots \ldots$

III Economic Models and Policies Designed to Reduce Greenhouse Gas Emissions . . . . . . 7

IV Sociopolitical Aspects of Global Warming $\ldots \ldots \ldots \ldots \ldots \ldots \ldots \ldots$

$\mathrm{V} \quad$ Security Implications of Global Warming $\ldots \ldots \ldots \ldots \ldots \ldots \ldots \ldots \ldots$

VI Discussion $\ldots \ldots \ldots \ldots \ldots \ldots \ldots \ldots \ldots \ldots \ldots \ldots \ldots \ldots \ldots \ldots \ldots$

VII Conference Program $\ldots \ldots \ldots \ldots \ldots \ldots \ldots \ldots \ldots \ldots \ldots \ldots \ldots \ldots \ldots \ldots$

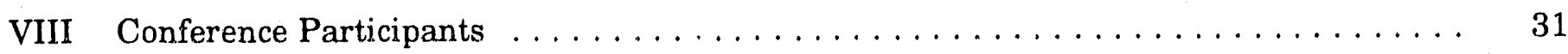




\section{Introduction}

On May 8-10, 1991, the Midwest Consortium for International Security Studies (MCISS) and Argonne National Laboratory cosponsored a conference on Global Climate Change and International Security. The aim was to bring together natural and social scientists to examine the economic, sociopolitical, and security implications of the climate changes predicted by the general circulation models developed by natural scientists. Five themes emerged from the papers and discussions: (1) general circulation models and predicted climate change; (2) the effects of climate change on agriculture, especially in the Third World; (3) economic implications of policies to reduce greenhouse gas emissions; (4) the sociopolitical consequences of climate change; and (5) the effect of climate change on global security. Sections I-V provide summaries of the formal talks that were presented for each of these themes. Section VI summarizes other issues that were developed during the discussion sessions that followed each talk. The program and a list of participants may be found in Sections VII and VIII.

The MCISS is an organization composed of universities that support graduate programs in international security studies. It was organized in 1986 to develop a program of interdisciplinary workshops and conferences that would encourage interactions among participants and foster networking that could lead to interinstitutional studies and projects. In carrying out its mission, the MCISS has sponsored workshops and conferences on various topics of concern to scholars studying security issues. These have included a series of workshops on various aspects of national security decision making in both the United States and the U.S.S.R., the ethics of low-intensity conflict, Congress and foreign policy, and the role of women in national security. Efforts have been made to include scholars from fields whose work is related but not traditionally seen as concerned with security issues. These fields include history, sociology, anthropology, religious studies, and ethics. In addition, graduate students are included as full participants in each activity.

The MCISS is managed by the American Academy of Arts and Sciences. Since 1987, it has been supported by a generous grant from the John D. and Catherine T. MacArthur Foundation. With renewed support from the MacArthur Foundation in 1990, MCISS expanded its field of concern to include security in the southeast Asia context, the impact of military expenditures and arms acquisitions on Third World security and development, the moral role of scientists with respect to the knowledge they generate, the implications of the restructuring of eastern Europe, and international security and global change.

Additional information about MCISS activities can be obtained from Dr. Rice, $5801 \mathrm{~S}$. Kenwood Avenue, Chicago, Illinois, 60637; (312) 753-8162. 


\section{Section I \\ Predicting Climate Change: \\ Certainties and Uncertainties of Physical Models}

Three speakers addressed this topic: Thomas Donahue, University of Michigan; John Firor, National Center for Atmospheric Research; and Douglas Sisterson, Argonne National Laboratory.

Thomas Donahue opered the conference with a descriptive overview of the general circulation models natural scientists have developed for the prediction of climate change. His remarks focused on the detection of global warming, the predictivo ability of the models, and their shortcomings.

The models are based primarily on the expected increase in the greenhouse gases carbon dioxide $\left(\mathrm{CO}_{2}\right)$, methane $\left(\mathrm{CH}_{4}\right)$, and the chlorofluorocarbons (CFCs). The information obtained by measuring the $\mathrm{CO}_{2}$ trapped in glacial ice over hundreds of years permits scientists to state with certainty that atmospheric $\mathrm{CO}_{2}$ has been increasing since the industrial revolution (Figure 1.1). Temperature records that have been maintained since 1870 show a definite increase in the earth's average surface temperature (Figure I.2). While the figure shows that there have also been some short-term decreases in the temperature, the overall trend is up.

Comparison of the temperature changes since 1870

with measured changes in atmospheric $\mathrm{CO}_{2}$ and

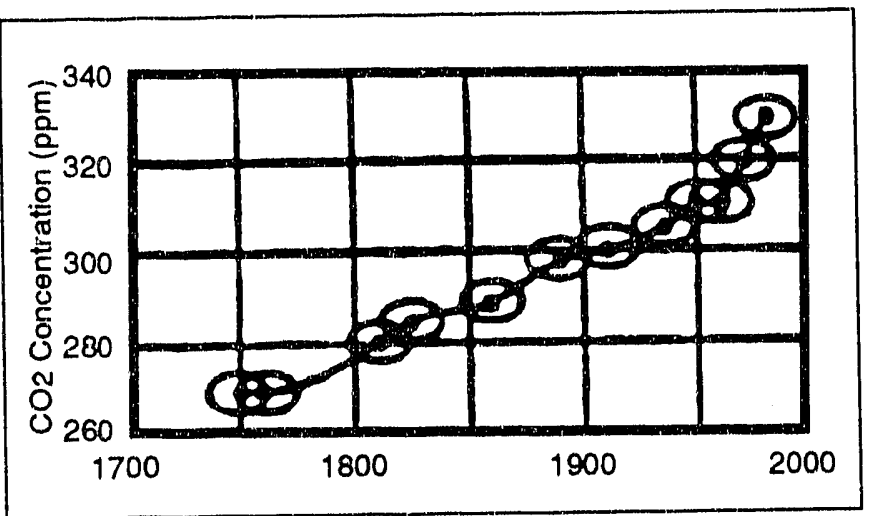

FIGURE I.1 Estimated Atmospheric Concentration of $\mathrm{CO}_{2}$ from Glacier Ice Samples
$\mathrm{CH}_{4}$ show a direct relationship between global temperature and the amount of $\mathrm{gr}$ ' enhouse gases.

Several models have been developed that predict the effective doubling of atmospheric $\mathrm{CO}_{2}$ by 2030 , with an average global temperature increase ranging from $1.5^{\circ}$ to $5.5^{\circ} \mathrm{C}$. The models differ in the assumptions regarding the mechanism of $\mathrm{CO}_{2}$ increase (i.e., continuous or instantaneous). They all agree that the global average surface temperature, global mean precipitation, northern polar winter temperature, and global sea level will increase, but they differ as to how large each change will be. The models are unable to predict the local variations in precipitation and the frequency of tropical storms.

A number of factors account for the uncertainties that contribute to the absence of a greater consensus on the part of modelers. One factor is clouds. Higher temperatures may produce more clouds, but will they be high-level clouds, which

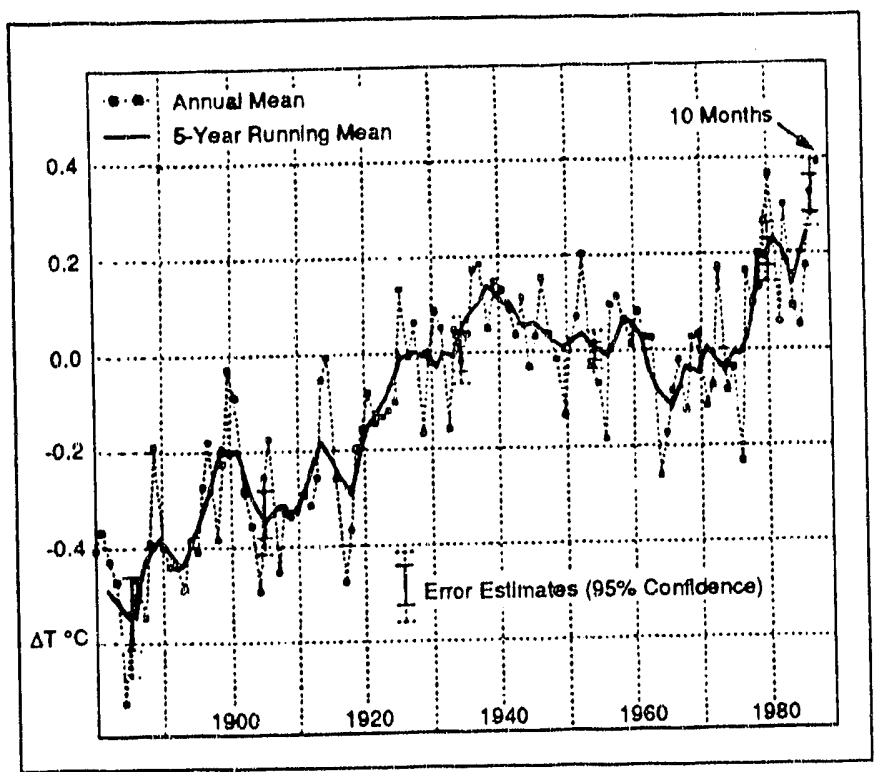

FIGURE I.2 Changes in Annual Mean Temperature since 1880 


\section{Predicting Climate Chango}

absorb nore infrared radiation, or low-level clouds, which reflect more sunlight back to space? Another uncertainty is the degree of convection intensification in the tropics, and a third uncertainty is the effect of the oceans in slowing the average rate of heating. More information is needed about the thermal capacity of oceans, their absorption of $\mathrm{CO}_{2}$, and the effects of currents on both. The ARM (Atmospheric Radiation Measurement) program, described by Douglas Sisterson later in this section, is gathering information about clouds and radiation transfer. Finally, the models divide the world into grids that are roughly 500 kilomeiers on a side. In order for their predictive ability to be more detailed, it would be necessary to use much smaller grids and to have computers with 500 times the capacity of those currently in use.

Our confidence in the models is based on their ability to predict the variation in temperatures between summer and winter, past ice ages, and the climate impact of phenomena such as El Niño. As it is difficult to quantify the error range of any individual model, it is likely that the overall range of all the models and the range of any single model may be the same. The difference in the predicted temperature increase from one model to another arises because of the differences in their treatment of clouds and oceans, both of which need, and are getting, more study. While the chemistry of the interaction of water and carbon dioxide molecules is well known, opinions differ about the capacity of the oceans to absorb $\mathrm{CO}_{2}$. Furthermore, the effect of higher temperatures on the $\mathrm{CO}_{2}$ output and absorption by trees and other plants is not known.

John Firor also spoke about climate modeling and noted that the use of computers for making models that can forecast the weather go back to the building of the first computer by von Neumann. Modern climate modeling is based on the work of L.F. Richardson, which began in 1912. His equations are still the starting point for most large climate models.

One important difference between models for forecasting weather and those for predicting climate change is that the latter utilize a fixed set of overall conditions, including the shape and size of the earth and the nature and composition of the atmosphere. Weather forecasting starts with a particular set of conditions (e.g., the weather at the moment) and calculates the progression of weather from that moment. Weather forecasts cannot be made beyond five or ten days, because as one moves away from the starting point, the errors build up; eventually, the information about the initial state is destroyed.

Dr. Firor affirmed that the variation in temperature predictions of the general circulation models is largely dependent on the way they treat clouds. If clouds are left out entirely and only blue skies are permitted, all the models give similar answers. Since the temperature increases predicted by the models differ by a factor of two, we can be fairly certain that the mechanisms for treating clouds are oversimplified. More information is needed about clouds: how they absorb moisture and release it as rain, how different kinds of clouds absorb radiation, etc. The federal government has recently made funds available to enhance research on this subject.

Although clouds are handled in a simplified way because we don't have sufficient information about them, their treatment can't be entirely wrong or the models would not work as well as they do for seasonal changes. Since we know the cause of seasonal temperature variations - namely, the position of the sun north or south of the equator this factor can be introduced into a model to see if it can correctly predict seasonal climate change.

The models also work fairly well in backcasting past climates, such as the period 900 years ago, when the orbit of the earth around the sun was somewhat different, and the late stages of the last ice age. When used to predict temperature changes for the future, the models foresee much more rapid temperature changes than the earth has experienced since the beginning of human civilizations. These are transient temperature changes because the oceans are not in equilibrium with the higher atmospheric temperatures. The oceans change more slowly than the atmosphere, and as the emission of $\mathrm{CO}_{2}$ continues and the temperature rises, they can't catch up.

Dr. Firor also spoke about the meaning of uncertainty, comparing the use of this term by scientists and its inappropriate use by many others. For example, there is no uncertainty that the temperature will rise with increasing atmospheric 
$\mathrm{CO}_{2}$; all the models agree on this. The uncertainty is in the extent to which it will rise. While the curves showing the increase in temperature for various models are average values that may be too high or too low, the increase will certainly not be zero. This use is to be contrasted with the uso of the term uncertainty in discussing whether one will miss a plane connection. In this case, there are only two possibilities: miss it or make it.

In concluding, he pointed out that despite the uncertainties of the models and the variations in predicted temperature rise, the policy implications are the same for all the models - namely, that steps should be taken to slow the increase in greenhouse gas emissions.

Douglas Sisterson summarized the work being carried out by the Atmospheric Research Section of the Environmental Research Division at Argonne National Laboratory. Two U.S. Department of Energy programs have been initiated to improve understanding of the energy balance and the radiative effects of clouds and to incorporate this information into the models. The ARM Program is examining the formation and properties of clouds and the transfer of radiation under various conditions (clear sky, broken clouds, generally overcast). How, for example, does the absorption of solar radiation vary with the type and height of a cloud?

Since cloud cover varies from place to place on a scale of tens of kilometers while the model's grids are 250-500 kilometers on a side, having the computer capacity to utilize a smaller grid size in the models would be useful. The CHAMMP (Computer Hardware, Advanced Mathematics Model Physics) Program is developing a parallel processing system in which many small computers are tied together. Each computer handles one small section of the model and transfers its information to a central computer that puts it all together. The data from the ARM Program instruments are recorded directly by the small computers and sent to a supercomputer for factoring into the climate models being tested. The computers also store the data so that if anyone wants to go back and use the actual measurements differently they are available.

The experimental program is called CART (Clouds and Radiation Testbed) system. Science team proposals are tested by data collection at a large number of climatologically important CART sites. An instrument development project is part of the program. The large number of measurement sites (five primary and five secondary) will enable comparisons of cluud formations and behavior with variations in land and ocean-surface temperatures. 


\section{Section II}

\section{Implications for Agricultural Production}

Vernon Ruttan reported on the implications for agricultural production of the preaicted climate changes. His presentation was based on his conclusions from a series of dialogues among agricultural, environmental, and health scientists concerning the constraints on sust:inable growth in agricultural production into the fi.'st decades of the 21 st century.

Until the 20th century, all increases in agricultural production were brought about by expansion of the area under cultivation, a source of production growth no longer available. In this century, fertilization, irrigation, and improvement in crop varieties have been the means of increasing food production. During this time, the real wheat and rice prices have decreased. However, irrigation is becoming even more expensive, the incremental gains from increased fertilization are declining, and the research effort needed to maintain current yields is becoming more costly. Advances in biotechnology and genetic engineering are the likely sources of increased yield in the coming years, but the research infrastructure required to develop these methods is very costly in both dollars and manpower. Furthermore, the promises of biotechnology are behind the predictions that were made for these techniques.

Population growth and growth in per capita consumption from higher incomes will place large demands on agricultural production. At the same time, there will be a number of constraints on increasing production. One of these is the increasing cost of maintenance research (e.g., the effort that keeps yields from declining as new pests evolve that attack the new, high-yield crop varieties). Another constraint on production is the health of agricultural workers. Factors causing health burdens range from a decline in the caloric intake of workers in a number of underdeveloped countries to infectious diseases and illness caused by the by-products from industrial and agricultural intensification, especially in the centrally planned economies. While the control of many infectious diseases and diarrheal disease has been marked, there has been little progress in the control of several parasitic diseases. In addition, the emergence of AIDS could pose a major threat to productivity.

The effect of global warming and other environmental changes will only exacerbate the problems described above. Global warming will result in rising sea levels that will inundate many river delta areas, especially in southern Asia. Drier and more erratic climate regimes are predisted for the interior crop-growing regions of southern Asia and North America.

The direct transfer of advances in science research in developed countries will not be sufficient to improve agricultural yields. The problems of tropical areas receive inadequate attention in the temperate, developed countries, and the farmers in developing countries must be educated in the use of new techniques. Hence, efforts must be made to institutionalize the agricultural research capacity in developing countries. This would include the establishment of substantial basic biological research and training capacity und the education of agricultural workers, especially in the tropical countries.

While they are certainly beneficial, conservation measures alone will not be sufficient to counteract global warming and its impact on agricultural production. Furthermore, conservation measures are frequently in conflict with traditional practices and thus are not readily adopted. The loss of soil due to erosion, water-logging, and salinization; groundwater contamination from plant nutrients and pesticides; and the growing resistance of insects, weeds, and pathogens to present methods of control will not be ameliorated by a preventionist approach alone, although increased energy efficiency and conservation would make significant contributions.

Professor Ruttan favors an adaptionist strategy (i.e., one that moves toward the design and implementation of new institutions). In addition to the 


\section{Section II}

development of incentive-compatible institutional design, a serious effort to develop alternative land use and farming and food systems is needed. The purpose of social science research should be to design institutions capable of achieving compatibility among individuals, organizations, and social objectives in resource management which is the meaning of "incentive-compatible institutions." $\mathrm{He}$ sees the design of needed institutions as a task of social scientists akin to the applied science activities of natural scientists. This task is typically carried out in an ad hoc fashion and left to policymakers alone, an approach that is inefficient. The U.S. management of water resources in the West is an example of a poorly managed resource because of the application of ad hoc, politically based solutions to a problem that affects a large region.

Ruttan also stressed the importance of knowledge transfer as opposed to technology transfer. Technology is location specific, which is why it is important to create site-specific research and training capacity. Developing countries can be helped most effectively when they have the capacity to take international knowledge and use it to solve local climate and crop problems. Furthermore, the development of indigenous research and technology systems will diminish their dependence on the West. Technology now increases production by $0.5-1 \%$ per year. Diversity in local crops, rather than dependence on big agribusiness, would be a better hedge against climate change. It was pointed out that any developing nation that owns two large military aircraft could have the funds for the needed agricultural research if it would choose to reassign the funding.

Some of the direct effects of climate change on agriculture were brought out during the discussion, and it was noted that global warming will provide more favorable conditions for agriculture in some areas such as Iceland, northern Europe, and the Soviet Union, while increasing the need for irrigation in many areas that are currently marginal. The development of salt-tolerant crops would be helpful as a means to combat the current salinization of cropland and also the salinization that might result from the expected rise in sea level.

While he agreed that improved distribution systems were important, Mr. Ruttan does not believe that they will solve the world's food problems. He expressed concern that farmers in poor countries are expected to increase their production by 3-5\%, while the West's best efforts in this area have resulted in a $2 \%$ annual growth.

The possibility of reducing the production and consumption of meat was explored. This would indeed reduce the demand for grains and soybeans, but it is not likely to become a policy. World experience has been that increased income leads to dramatically increased consumption of animal fat and protein. It was noted that a global food stamp program could cost the United States and the European Economic Community (EEC) the same amount that they currently spend for farm price supports in their own countries. 


\section{Section III}

\section{Economic Models and Policies Designed to Reduce Greenhouse Gas Emissions}

Economists are generating models to predict the effect of various policies designed to ameliorate the consequences of global climate change. These have even greater uncerliainty than the climate models. However, the prognosis seems favorable for improving the models as economists learn more about economic systems. For the present, all the speakers agreed that shocking the economy with sudden policy chariges would be certain to have a drastic effect on GNP and economic growth, but that gradual policy changes that would allow the system to respond slowly could be tolerated. Five speakers addressed these issues: Richard Kosobud, University of Illinois at Chicago; Robert Ayres, Carnegie Mellon University; and Don Hanson, David South, and David Streets, Argonne National Laboratory.

Richard Kosobud described and analyzed a market approach to policies that would limit greenhouse gas emissions based on a balancing of the abatement costs and the marginal social benefit. $\mathrm{He}$ noted that even in a situation of considerable scientific uncertainty, estimating the cost of doing nothing now and finding that we have to move suddenly and rapidly versus the cost of doing something and finding later that we have moved too fast and incurred unnecessary costs provides a useful framework for analysis. He emphasized the benefits of policies that bring about change gradually as opnosed to sudden changes that shock the economy, and he emphasized his belief that policies that utilize market forces to reduce $\mathrm{CO}_{2}$ emissions are the most likely to succeed.

A comparison of the cost of emission reduction versus the social damage cost of $\mathrm{CO}_{2}$ emissions highlights the advantages of a market approach. As emissions are reduced, increasing costs are incurred to lower them. On the other hand, as emissions are reduced, social damage costs also fall. The point at which the costs become equalized indicates the economic point for emission abatement. While we may not be certain how to reduce emissions, it will be very costly not to make a'start. The numbers suggest that moderate ahatement efforts (e.g., slowing deforestation and emissions of CFCs and $\mathrm{CO}_{2}$ ) are warranted now.

In developing a market approach to emission reduction, one looks for a policy that is efficient (e.g., exhibits cost effectiveness), flexible (easily changed as more data are gathered), and equitable both within the United States and globally. For example, controlling acid rain through the required use of scrubbers was not a cost-efficient solution because it necessitated micromanagement of a macropolicy. On the other hand, assessment of a carbon tax to reduce emissions of $\mathrm{CO}_{2}$ would meet the policy requirements. It would also provide a market incentive to reduce fossil fuel consumption by raising its cost. Hence, a tax on carbon, Btu's (heat content), or some other factor directly related to fuel use would reduce emissions.

Issuing permits to emit $\mathrm{CO}_{2}$ is another market approach. Permits could be issued to a world bank that would distribute them as it saw fit. If the number of permits issued were to stabilize emissions at 1990 levels (Scenario A in Figure III.1), then drastic measures would be needed to comply with this policy. Assuming that permit trading were permissible, it can be calculated that the cost of prohibiting any increase in emissions would drive the price of a permit to $\$ 70$ in the first five years and to $\$ 200$ by 2075 . However, if the number of permits issued were to allow for a small increase in emissions but to require cuts in later years until emissions were reduced sharply (Scenario $A^{\prime}$ ), the price would rise by only $\$ 5$ in the first five years. By 2075 , the price would leap to $\$ 237$, and by 2100 , the market would have largely phased out $\mathrm{CO}_{2}$ emissions. The second plan is superior because it would work well over time, whereas the first scheme would force expensive adjustments $n$ the finssil fuel industry in the short run because of the high cost for 

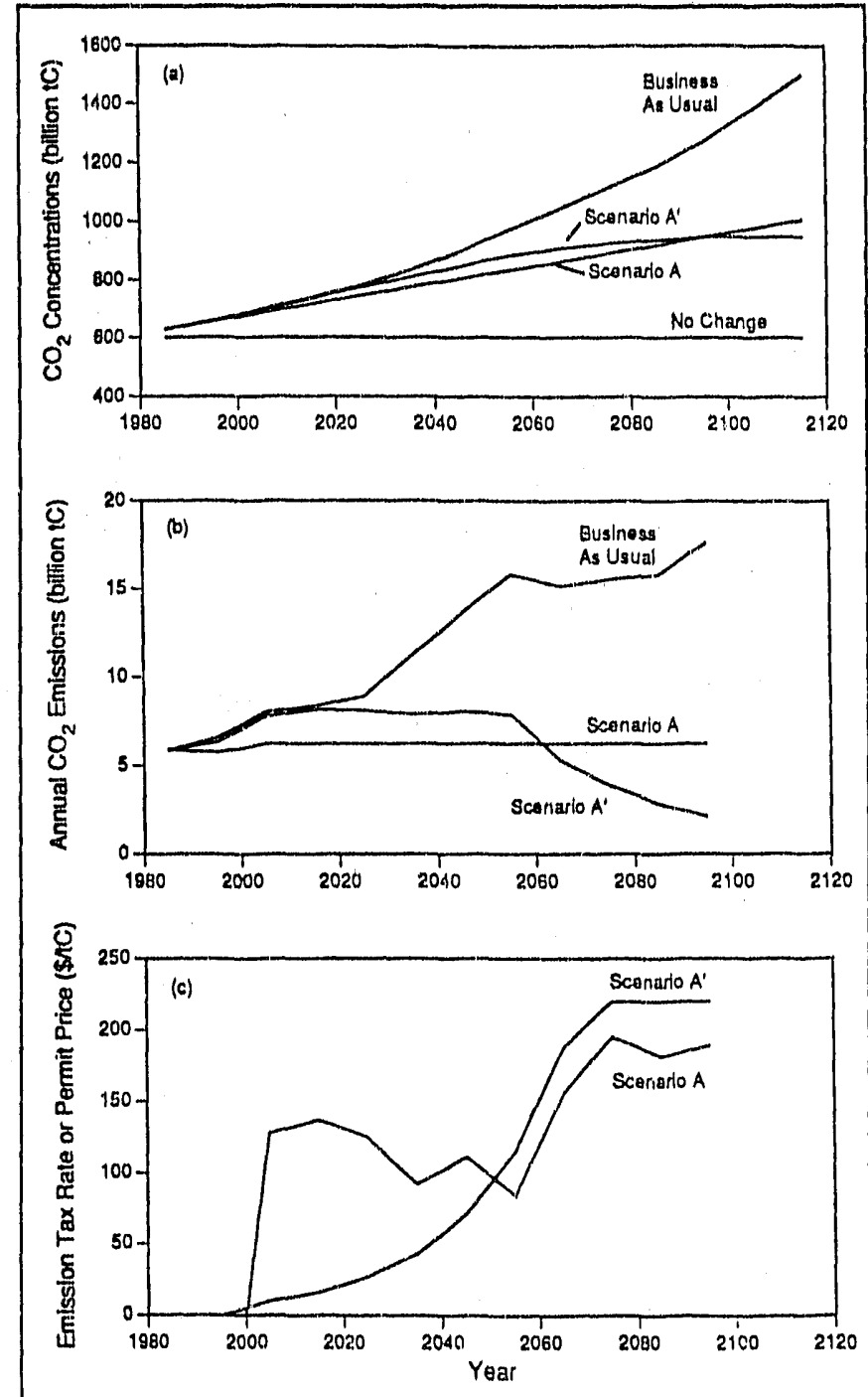

\section{FIGURE III.1 Permit Policy Scenarios}

compliance with the drastic policy. Another method for handling permits might be to issue the bulk of permits to developing nations and allow those nations to keep them for their own use or sell them to gain wealth.

Robert Ayres mentioned a series of studies at Carnegie Mellon Institute and elsewhere that strongly suggest that energy conservation is the least costly method of reducing $\mathrm{CO}_{2}$ emissions. Tinese studies imply that the economy is now in a state of equilibrium and that a lowest-cost mix of energy technologies has already been selected. Professor Kosobud was skeptical, noting that there are costs in making behavioral changes and that if there were a monetary benefit from conservation methods, market forces would be bringing those methods into practice now. Professor Ayres challenged this assertion, pointing out that returns to investment in conservation are currently much higher than returns to investment in new energy supplies.

Addressing the question of how to handle equity issues for different countries, given the difficulties in measuring equity within a single society, Professor Kosobud pro'josed that one way might be to compare each country's energy use over time. In this case, for example, the United States and Canada use less energy per capita now than they did in 1890. Europe's energy use per capita is the same, but the developing countries' per capita use is greater than it was in 1890 and is increasing. Another method might be to issue permits on the basis of population. If an area's population were to increase, it would need to buy permits; whereas if its population were to decrease, it could sell its permits. In both cases, the price would be determined by market forces. The system for issuing permits could be a topic for international negotiation.

David Streets described some of the research being done by the Policy and Economic Analysis Group at Argonne National Laboratory. In the area of climate change, it has been studying the impact of various energy policies and technclogies on the economy and the environment. One study was designed to examine policy options that have as their goal the reduction of $\mathrm{CO}_{2}$ emissions by the energy utilities by $20 \%$ by 2000 and $50 \%$ by 2010 . With no controls on emissions or fuel use, $\mathrm{CO}_{2}$ concentrations are expected to double by 2010 . Dr. Streets's calculations show that a carbon tax on all fossil fuels used by the utility industry would be very costly and would do little to reduce emissions. However, a tax on coal would result in a much larger reduction in emissions at a somewhat smaller cost. On the basis of this type of research, it has been found that a successful emissions reduction policy would require controls on both the demand and supply sides, a revitalization of nuclear power, and eventual phasing out of all carbon fuels. The same policies would have to be carried out for transportation and major industry. 
David South spoke about the energy implications of climate change, focusing on research on energy policies and the role of new fossil fuel technology in reducing the greenhouse effect. One difficulty in developing and maintaining an energy policy is that the price of oil is not stable. If the price of oil falls, so does the incentive to develop alternate energy systems. He emphasized the need for research to develop more efficient fuel technologies to reduce the consumption of fossil fuel and the emission of greenhouse gases. Since the United States imports over half of its oil, market considerations (the price of crude vil, the reliability of supply, and energy trading) and the political stability of oil-producing countries heevily influence capital investisent in alternate technologies.

(Alternate technologies include efforts to improve the efficiency of fossil fuels as well as the development of alternate sources of energy). Since the world's fossil fuel reserves are considerable, more efficient methods for fossil fuel use are a key to reductions in $\mathrm{CO}_{2}$ emissions.

The five greenhouse gases $-\mathrm{CO}_{2}, \mathrm{CH}_{4}$, nitrous oxide $\left(\mathrm{N}_{2} \mathrm{O}\right)$, ozone $\left(\mathrm{O}_{3}\right)$, and the CFCs - are not produced in equal amounts, nor is their infraredabsorbing capacity equal. Policy analyses are based on assumptions regarding expected changes in the production of the greenhouse gases. It is assumed that emissions will continue to increase rapidly in eastern Europe, Asia, and the developing countries; level off in the United States; and remain constant in western Europe and the Pacific (see Figure III.2). Thus, the North American share in the rate of increase will decrease over time, while the share of the less developed countries may surpass that of the developed countries. The development potential and aspirations of less developed countries will have to be considered in establishing global policies for the reduction of emissions.

Coal is the world's main fuel resource and thus will continue to be in use for some time. Assuming fuel is traded, then at the current rate of production, coal reserves should last 325 years, while oil and gas reserves should only last 50 years. Eight nations have $81 \%$ of the world's fossil fuel reserves; these include the United States, Germany, China, and the U.S.S.R. If China were the only country to use Chinese coal, coal reserves would last 700 years.

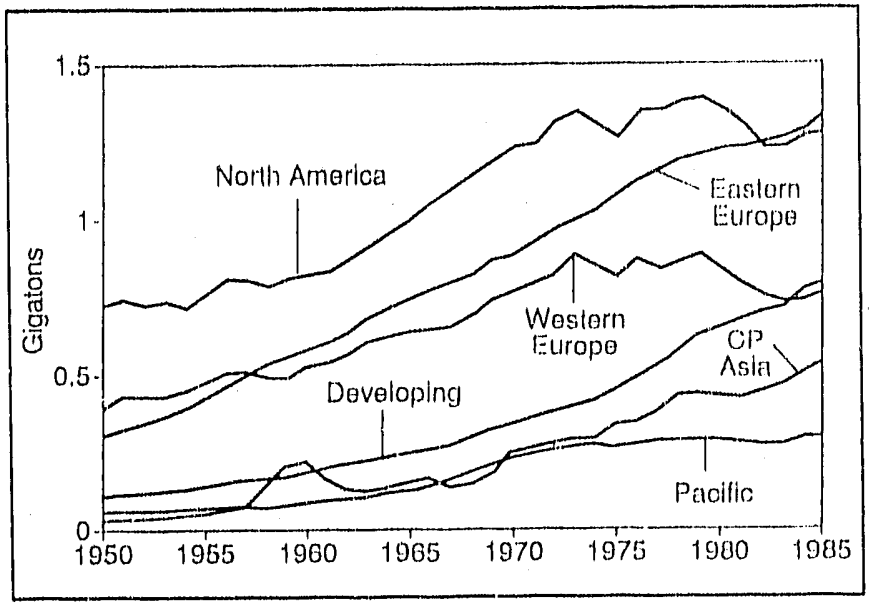

\section{FIGURE III.2 Shifting Patterns of Fossil- Fuel-Related $\mathrm{CO}_{2}$ Emissions (Source: LPA, 1989, Policy Options for Stabilizing Global Climate)}

The Edmonds-Riley Oak Ridge model of energy needs through the next century predicts that energy growth in the developed countries will be about $1 \%$ per year, while the growth rate will be $8 \%$ per year in the developing countries. In addition, most Asian coals contain little sulfur but have a high ash content and are not heat efficient, which means their contribution to atmospheric $\mathrm{CO}_{2}$ is relatively larger.

As a result of a look toward the 1992 United Nations Conference on the Environment and Development to be held in Brazil, various activities to reduce greenhouse gas emissions have been initiated. A number of European countries have set goals for the reduction of greenhouse gases to be implemented by the imposition of carbon taxes (see Table III.1). These policies generally have the caveats that they should not interfere with trade and that other nations should be pursuing similar policies. Most European countries have had high taxes on gasoline for many years. The United States is committed to increasing understanding of the scientific and econnmic effects of climate change in order to develop sound knowledge on which to base policy. Bills introduced in Congress during the last two sessions called for limiting the use of fossil fuels and setting ma:ket shares for renewable fuels. Senator Gore has introduced a bill that calls for switching to noncarbon fuel sources of power, 
TABLE III.1 Greenhouse Gas (GHG) Positions of Developed Countries

\begin{tabular}{|c|c|c|c|c|c|}
\hline \multirow[b]{2}{*}{ Country } & \multirow{2}{*}{$\begin{array}{l}\text { Emissions } \\
\text { Target }\end{array}$} & \multirow[b]{2}{*}{ Gases } & \multicolumn{2}{|c|}{ Time Frame } & \multirow[b]{2}{*}{ Level of Commitment and Contingencies } \\
\hline & & & Base & Target & \\
\hline Australia & $\begin{array}{l}\text { Stabilize } \\
\text { Reduce } 20 \%\end{array}$ & All $\mathrm{GHGs}^{\mathrm{a}}$ & $\begin{array}{l}1988 \\
1988\end{array}$ & $\begin{array}{l}2000 \\
2005\end{array}$ & $\begin{array}{l}\text { Interim planning target, contingent on avoidance of } \\
\text { net adverse economic impacts and on similar actions } \\
\text { by other countries }\end{array}$ \\
\hline Austria & Reduce $20 \%$ & $\mathrm{CO}_{2}$ & 1987 & 2005 & $\begin{array}{l}\text { Major irtention of energy policy, needs parliamentary } \\
\text { approval }\end{array}$ \\
\hline Belgium & Reduce $5 \%$ & $\mathrm{CO}_{2}$ & 1990 & 2000 & Nonbinding, preliminary objective \\
\hline Canada & Stabilize & All GHGs & 1990 & 2000 & Planning goal, not yet instituted \\
\hline Denmark & $\begin{array}{l}\text { Stabilize } \\
\text { Reduce 20\% }\end{array}$ & $\mathrm{CO}_{2}$ & $\begin{array}{l}1988 \\
1988\end{array}$ & $\begin{array}{l}2000 \\
2005\end{array}$ & $\begin{array}{l}\text { Implementation provided for in national energy plan } \\
\text { Revisions to plan permitted to help ensure fulfillment } \\
\text { of targets }\end{array}$ \\
\hline $\begin{array}{l}\text { Eluropean } \\
\text { Community } \\
(\mathrm{EC})^{\mathrm{b}}\end{array}$ & Stabilize & $\mathrm{CO}_{2}$ & 1990 & 2000 & $\begin{array}{l}\text { Nonbinding decision, applies to community-wide level, } \\
\text { not each member country }\end{array}$ \\
\hline E.F.T.A. & & & & & Has agreed to adopt the $\mathrm{EC}^{\prime} \mathrm{CO}_{2}$ stabilization target \\
\hline Finland & & $\mathrm{CO}_{2}$ & & & Considering targets, has established carbon tax \\
\hline France & $\begin{array}{l}\text { Per capita } \\
\text { stabilization }\end{array}$ & $\mathrm{CO}_{2}$ & & 2000 & $\begin{array}{l}\text { Part of environmental plan approved by Nationa! } \\
\text { Assembly; per capita carbon target of two metric tons } \\
\text { well above recent levels }\end{array}$ \\
\hline \multirow[t]{2}{*}{ Germany } & $\begin{array}{l}\text { Reduce } 25 \% \\
\text { (30\% target) }\end{array}$ & $\mathrm{CO}_{2}$ & 1987 & 2005 & $\begin{array}{l}\text { Fairly high degree of commitment; lacks } \\
\text { programmatic provisions (suggested as response to } \\
\text { last year's unification of the two Germanies) }\end{array}$ \\
\hline & Control & $\mathrm{CH}_{4}$ & & & Whenever possible \\
\hline Iceland & Stabilize & GHGs & 1990 & 2000 & Proposal \\
\hline Italy & $\begin{array}{l}\text { Stabilize } \\
\text { Reduce } 20 \%\end{array}$ & $\mathrm{CO}_{2}$ & $\begin{array}{l}1990 \\
1990\end{array}$ & $\begin{array}{l}2000 \\
2005\end{array}$ & $\begin{array}{l}\text { Ministerial proposal and nonbinding parliamentary } \\
\text { resolution }\end{array}$ \\
\hline Japan & $\begin{array}{l}\text { Per capita } \\
\text { stabilization }\end{array}$ & $\mathrm{CH}_{4}, \mathrm{~N}_{2} \mathrm{O}$ & 1990 & 2000 & $\begin{array}{l}\text { Preliminary, conditioned on feasibility and } \\
\text { international actions; suggested stabilization of total } \\
\text { emissions some time after } 2000 \\
\text { Efforts to be pursued }\end{array}$ \\
\hline Luxembourg & Reduce 20\% & $\mathrm{CO}_{2}$ & 1990 & 2005 & No additional background on Luxembourg position \\
\hline
\end{tabular}




\section{TABLE III.I (Cont'd)}

\begin{tabular}{|c|c|c|c|c|c|}
\hline Country & $\begin{array}{l}\text { Emissions } \\
\text { Target }\end{array}$ & Gases & Base & Target & Level of Commitment and Contingencies \\
\hline Netherlands & $\begin{array}{l}\text { Stabilize } \\
\text { Reduce } 3-5 \%\end{array}$ & $\mathrm{CO}_{2}$ & $\begin{array}{l}1990 \\
1990\end{array}$ & $\begin{array}{l}1995 \\
2000\end{array}$ & $\begin{array}{l}\text { Major part of national environmental policy } \\
\text { Committed to unilateral targets as a means to spur } \\
\text { multilateral efforts }\end{array}$ \\
\hline New Zealand & Reduce $20 \%$ & $\mathrm{CO}_{2}$ & 1990 & 2000 & $\begin{array}{l}\text { Proposed objective, implicitly conditioned on } \\
\text { international action }\end{array}$ \\
\hline Norway & Stabilize & $\mathrm{CO}_{2}$ & 1989 & 2000 & $\begin{array}{l}\text { Preliminary, unilateral policy linked to technological } \\
\text { and international developments }\end{array}$ \\
\hline Switzerland & Stabilize & $\mathrm{CO}_{2}$ & & 2000 & $\begin{array}{l}\text { Interim planning target of energy prograza adopted in } \\
\text { referendum }\end{array}$ \\
\hline U.K & Stabilize & $\mathrm{CO}_{2}$ & 1990 & 2005 & $\begin{array}{l}\text { Nonbinding proposal, contingent on like action by } \\
\text { other nations }\end{array}$ \\
\hline United States & Stabilize & All GHGs & 1987 & 2000 & $\begin{array}{l}\text { Declared result of various actions, most of which have } \\
\text { been enacted }\end{array}$ \\
\hline $\begin{array}{l}\text { Greece, Ireland } \\
\text { Portugal, Spair }\end{array}$ & & & & & $\begin{array}{l}\text { No official positions, but would be obliged to support } \\
\text { EC target. }\end{array}$ \\
\hline
\end{tabular}

${ }^{2}$ Excluding substances - principally chlorofluorocarbons ( $\mathrm{CFCs}$ ) - that deplete the beneficial stratospheric ozone layer and are covered by the Montreal Protocol (see note). Such non-CFC GHGs include $\mathrm{CO}_{2}$, methane $\left(\mathrm{CH}_{4}\right)$, $\mathrm{N}_{2} \mathrm{O}$, and tropospheric ozone $\left(\mathrm{O}_{2}\right)$.

brwelve-member organization: Belgium, Denmark, France, Germany, Greece, Luxembourg, Ireland, Italy, the Netherlands, Portugal, Spain, and United Kingdom (UK).

'European Free Trade Association, a nonsovereign group of six nations: Austria, Finland, Iceland, Norway, Sweden, and Switzerland. (Liechtenstein is an associate member.)

dIf expected population growth is incorporated, Fra ace's $\mathrm{CO}_{2}$ emissions would be allowed to increase by as much as $15 \%$ to $20 \%$ over the 1988 level by the year 2000 .

Note: The above countries are presumed to eliminate the production of ozone-depleting substances pursuant to the Montreal Protocol as amended in 1990, which calls for the phase out of CFCs (a group of potent GHGs) by 2000. Several of these countries intend to eliminate CFCs anywhere from three to five years earlier.

Sources: Compilations that were reviewed: International Energy Agency, Su.nrnary of Actions in Member Countries to Deal with the Issue of Climate Change, IEA/SLT(90)51 (2nd Revision), Paris, France (February 1991); and U.S. State Department Matrix, Emissions Targets and Timetables: Other OECD Countries, OES/OGC (February 1991). 
permits trading in emission allowances, and levels a tax on coal use to reduce emissions by $20 \%$ by 2010 . However, to date, no firm policy has been enacted.

Of the possible methods siggested for reducing greenhouse gas emissions (a tax on carbon, a tax on Btu's, a gas tax, an added value tax), the tax on carbon seems to be the one most commonly proposed. In the United States, to obtain a $20 \%$ reduction in $\mathrm{CO}_{2}$ by 2010 , it would be necessary to levy a tax of from $\$ 50$ to $\$ 500$ depending on the model selected. As Professor Kosobud noted in his presentation, these figures illustrate the consequences of sudden and rapid policy changes. On the other hand, a high tax would encourage the development of alternate fuels and techniques to increase fuel efficiency, and it may be the only way to do so. If the United States doesn't develop these technologies, heavy coal users, such as China, certainly won't.

Robert Ayres spoke about the work of the Department of Engineering and Public Policy at Carnegie Mellon University and about his own research interests in climate change. The department is looking at a range of activities, including the human behavior and natural processes that produce greenhouse gases, the role of uncertainty and risk, and human responses to specific climate changes. Federal research on climate change is mostly directed to studies of physical processes and is small in scope. Furthermore, the applied aspects are not always optimally selected to lead to better policy-making.

The department is interested in formulating an integrated approach that would identify the actors, the outcomes that matter, the uncertainties in our knowledge, and the research needed to reduce them. Support for these policy studies has come from the Electric Power Research Institute, U.S. Department of Energy, and the National Science Foundation.

Professor Ayres's own work focuses on the stabilization of the biosphere (Figure III.3). In summing up the history of the earth, he noted that it was originally a reducing system. Over the years it became more acidic, a process that halted with the arrival of life on earth. Since that time, the pH of the oceans has been fairly constant. The arrival of life resulted in the closure of the carbon cycle by

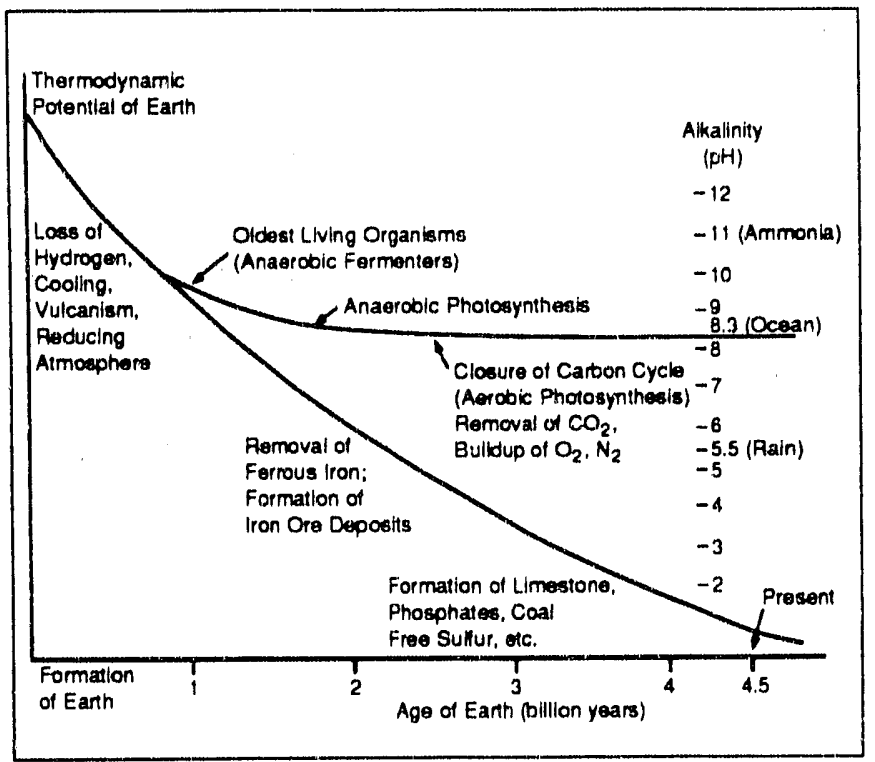

FIGURE III.3 Biosphere Stabilization

which $\mathrm{CO}_{2}$ and water are used by plants to produce sugars and free oxygen. Previous life forms destroyed their own atmosphere by using existing oxygen and tying it up in compounds.

Referring to the diagram shown in Figure III.4, he noted that the earth is now in a quasi-stable state in a system that is far from equilibrium. It is not clear how much the system can be perturbed without being shifted to another stable state, if there is one. At presunt, science cannot tell us if the other states exist, and possibly we can never know. He believes it is dangerous to alter the environment when the consequences are not known; therefore, his research will be directed toward trying to answer the three questions that follow. The effort will be multidisciplinary and should include natural scientists, economists, and ethicists.

1. Is it technically feasible to have a truly sustainable economic system that could exist in balance with the biosphere without disturbing the system? This would mean a system in which greenhouse gases would not increase and there would be no further increase in acidification of the earth nor any build-up of heavy toxic metals in soils and sediments. The economic implications of such a system would certainly include a reduced use of fossil fuels, alihough the present level might be sustainable. 


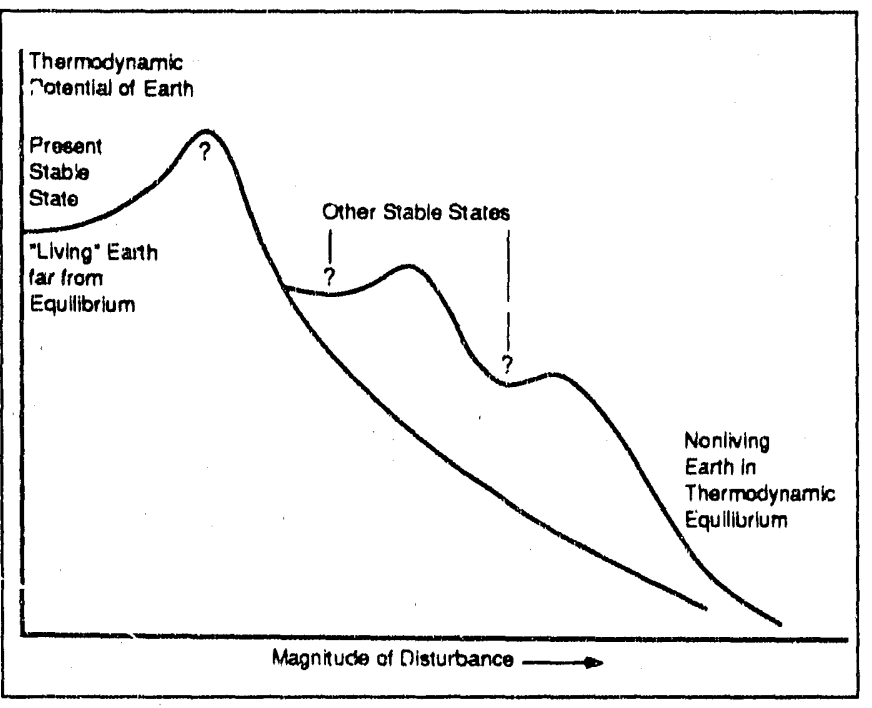

FIGURE III.4 A Risky Experiment

2. Is it physically and economically possible to stabilize the population over the next 50 years via education and changes in attitudes?

3. What is the least costly path to this stable state?

Don Hanson spoke about the development and use of macroeconomic models to suddy the effects on the GNP of various policies that might be invoked to mitigate the effects of climate change by a reduction in $\mathrm{CO}_{2}$ emissions. He agreed with Professor Kosobud that we should be looking for ways to reduce greenhouse gases that will not have a strong impact on the economy. Policies being examined include a tax on carbon, issuance of permits, financing reforestation, conservation programs, and the development of alternate fuels.
To reduce fossil fuel usage by a significant amount, a very large carbon tax would be needed. Although the effects of a $\$ 100$-per-ton carbon tax on GNP are not uniform over time, the peak GNP losses in a year were estimated to be about $3 \%$. A carbon tax could reduce the federal government's deficit or even turn it into a surplus. Oil imports and possibly world oil prices would decrease somewhat, which could be seen as an increase in energy security. The channels through which energy or carbon taxes may affect the macroeconomy were discussed, as was the simulation of energy conservation programs in a macroeconomic model.

In a model that uses 400 equations, there are clearly going to be difficulties in getting, all the factors properly accounted for. Some believe that the information that can be expected from the new physical measurements in many regions (as described by Douglas Sisterson) will reduce uncertainty about the range of climate change. It is also possible that these measurements will enable climatologists to improve regional predictions of precipitation levels and of the frequency of severe storms without narrowing the range of global temperature change. Others believe that new knowledge may narrow some uncertainties but also uncover new ones. Yet a fourth stance recognizes that $\mathrm{CO}_{2}$ in the atmosphere will certainly increase, and since it can take 20 to 50 years to put infrastructure changes in place, it would be best to initiate policies aimed at reducing $\mathrm{CO}_{2}$ emissions now. A conservation program cannot be harmful and has the added benefit of $p$-oviding for better management of natural resources. Furthermore, whatever the best estimate of the temperature change will be, the range of policy options for reducing emissions will not vary. Therefore, waiting will not clarify the policy choices. 


\section{Section IV}

\section{Sociopolitical Aspects of Global Warming}

Two participants addressed this topic: Roger Kasperson of Clark University and Ata Qureshi, the director of the Climate Research Institute.

Roger Kasperson spoke about some of the sociopolitical concerns that arise in dealing with the problem of greenhouse gas emissions. These include apprising society of the risks associated with global warming, establishing a constituency that could lead to the development of public policies to meet the problems, providing the necessary clarity on equity issues so that they can be addressed in public policy, and building an international regime that can work to alleviate the consequences of the predicted climate change. Figure IV.1 presents a set of interrelationships that must be recognized in order to address the consequences of global warming.

Since people don't have direct experience with the greenhouse effect, individual understanding of its hazards is dependent on mass media coverage. Partly driven by the drought of 1988, worldwide coverage of greenhouse gas emissions has increased dramatically, apparently even in the developing countries. However, the form of the coverage simplifies the issues and emphasizes the question "Who is to blame?" rather than "What are the risks?" and "How can they be overcome?"

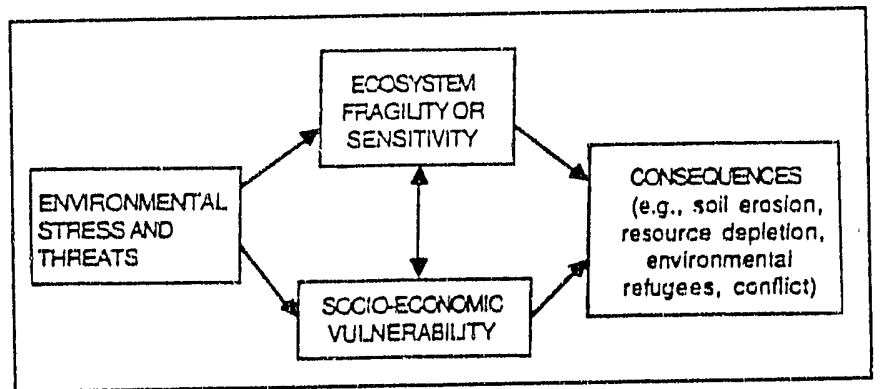

FIGURE IV.1 Interrelationships Important in Global Warming
Another difficulty with mass media coverage is that it tends to look for ways to develop dramatic stories as opposed to the presentation of straightforward science reports. Often drama is created by presenting two opposing scientific views about a particular aspect of the issue - not necessarily extreme views, but views that represent a conflict of opinion about the interpretation of the data - thus castir.g doubt on the accuracy of scientific information. In the process, areas of scientific consensus often do not get enough attention.

Current public perceptions of the greenhouse effect recognize that greenhouse gases are increasing. However, despite the 1988 drought, the problem is not high on the list of public concerns in the United States, where polls show that air and drinking water quality, soil erosion, and chemical waste are of much greater concern (Tables IV.1 and iv.2). There has not been much cross-national polling, but one recent Harris poll is encouraging in that it shows that while the same three items rank above worsening climate, people in developing countries are becoming concerned about environmental issues (Table IV.3).

If we assume that the mass media will continue presenting its episodic coverage of climate change issues based on differing scientific views as opposed to presenting the scientific information directly, how might we expect public opinion to be affected? Two other environmental problems that received similar treatment had different outcomes. In the case of nuclear power, the message from a frightened public to politicians and utility planners continues to be "Avoid it at all costs." In the case of acid rain, the public may be more confused now than it was ten years ago, despite an enormous amount of information. Nevertheless, an acid rain agreement was negotiated ir 1990. Public response to climate change issues could go either way, depending on the action taken by the environmental groups, the evolution of the policy debate, and competing issues. Will the environmental groups be able to keep the problem of greenhouse gas emissions before the public during a period of years when research will 
TABLE IV.1 Perceived Seriousness of Some Environmental Problems

\begin{tabular}{lrrrr}
\hline \multicolumn{1}{c}{ Problems } & $\begin{array}{c}\% \\
\text { Don't } \\
\text { Know }\end{array}$ & $\begin{array}{c}\% \\
\text { Not Too } \\
\text { Serious }\end{array}$ & $\begin{array}{c}\% \\
\text { Somewhat } \\
\text { Serious }\end{array}$ & $\begin{array}{c}\% \\
\text { Very } \\
\text { Serious }\end{array}$ \\
\hline Active Hazardous Waste Sites & 3 & 6 & 29 & 62 \\
Abandoned Hazardous Waste Sites & 5 & 6 & 28 & 61 \\
Worker Exposure to Toxics & 5 & 6 & 29 & 60 \\
Industrial Water Pollution & 2 & 11 & 29 & 58 \\
Nuclear Accident Radiation & 2 & 13 & 27 & 58 \\
Radioactive Waste & 4 & 10 & 31 & 54 \\
Underground Tank Leaks & 4 & 10 & 32 & 54 \\
Pesticide Harm to Users & 5 & 11 & 30 & 54 \\
Pesticide Residue & 2 & 12 & 34 & 52 \\
Industrial Accident Pollution & 3 & 9 & 37 & 51 \\
Farm Runoff Water Pollution & 2 & 13 & 37 & 48 \\
Ozone Layer Destruction & 8 & 11 & 34 & 47 \\
Ocean Coastal Water Contamination & 6 & 14 & 33 & 47 \\
Sewer Plant Water Pollution & 5 & 19 & 31 & 45 \\
Vehicle Exhaust & 2 & 18 & 42 & 38 \\
Oil Spills, Tankers, Rigs & 5 & 22 & 35 & 38 \\
Acid Rain & 12 & 17 & 35 & 36 \\
Urban Runoff: Water Pollution & 4 & 23 & 38 & 35 \\
Damaged Wetlands & 9 & 20 & 36 & 35 \\
Genetic Alteration Damage & 18 & 16 & 31 & 35 \\
Nonhazardous Waste Sites & 3 & 25 & 39 & 33 \\
Greenhouse Effect & 13 & 17 & 37 & 33 \\
Indoor Air Pollution & 3 & 34 & 37 & 26 \\
X-Ray Radiation & 5 & 42 & 31 & 22 \\
Indoor Radon Air Pollution & 19 & 30 & 30 & 21 \\
Microwave Oven Radiation & 6 & 61 & 19 & 14 \\
\hline
\end{tabular}

Source: The Roper Organization, data from national polls taken in December 1987 and January 1988.

probably narrow some issues while enlarging others? The answer remains, "We don't know." However, a poll recently published by Time provides some tentative indication that the public may be responding to the greenhouse gas effect by softening its stand on nuclear power (Table IV.4).

How to deal with the equity issues that are raised by assigning responsibility for solving the problems related to climate change was a major topic of Mr. Kasperson's presentation. Table IV.5 lists five views on assigning responsibility for the current problem. What are the factors that should be taken into consideration? Emissions of $\mathrm{CO}_{2}$ from dergloping countries have been increasing rapidly (Figure III.2), and this pattern is expected to continue (Table IV.6). On the other hand, Figure III.2 also shows that fossil-fuel-related emissions from the developed nations are overwhelmingly respon$s$ ble for the current levels of greenhouse gases. An examination of the current per capita emissions of greenhouse gases (Table IV.7) shows that both developed and developing countries are among the highest and lowest emitters. 


\section{TABLE IV.2 Perceived Threats to Personal Health and Safety and Overall Environmental Quality from Selected Environmental Hazards ${ }^{a}$}

\begin{tabular}{|c|c|c|}
\hline \multirow[b]{2}{*}{ Hazard } & \multicolumn{2}{|c|}{$\begin{array}{c}\text { Health and Safety } \\
\text { Threat }(\%)\end{array}$} \\
\hline & 1987 & 1989 \\
\hline Hazardous Waste Disposal & 62 & 69 \\
\hline Air Pollution, General & 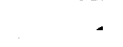 & - \\
\hline Underground Water Contamination & 47 & 65 \\
\hline Pollution of Rivers, Lakes, Oceans & 46 & 60 \\
\hline Food Additives and Pesticides & 49 & 60 \\
\hline Atmospheric Ozone Depletion & 39 & 58 \\
\hline Air Pollution, Business & 37 & 58 \\
\hline Air Pollution, Car and Trucks & 32 & 52 \\
\hline Greenhouse Effect & 20 & 48 \\
\hline \multirow[t]{2}{*}{ Acid Rain } & 33 & 43 \\
\hline & \multicolumn{2}{|c|}{$\begin{array}{l}\text { Environmental } \\
\text { Quality Threat } \\
(\%)\end{array}$} \\
\hline Hazardous Waste Disposal & 65 & 71 \\
\hline Air Pollution, General & 47 & 67 \\
\hline Underground Water Contamination & 52 & 67 \\
\hline Pollution of Rivers, Lakes, Oceans & 54 & 67 \\
\hline Food Additives and Pesticides & 49 & 55 \\
\hline Atmospheric Ozone Depletion & 42 & 61 \\
\hline Air Pollution, Business & - & - \\
\hline Air Pollution, Car and Trucks & - & - \\
\hline Greenhouse Effect & 26 & 52 \\
\hline Acid Rain & 38 & 53 \\
\hline
\end{tabular}

${ }^{a}$ Numbers indicate percentages of answers that considered the hazard a "large" threat (i.e., gave it a score of 6 or 7 on a 1-7 point scule). The question asked was, "Using a scale from 1 to 7 , where 1 means "no threat at all" and 7 means "a large threat," how much does each of the following problems threaten (1) your personal health and safety and (2) the overall quality of the environment?

Source: Cambridge Reports, Inc., The New Greening of America, Strategic Publication Series No. 202, Cambridge Reports 1990, p. 4-5.

As early as 1950 , Gilbert White noted that environmental damage is a product of the release of contaminants, their interaction with the ecosystem (a measure of its fragility), and the social and economic vulnerabilities of the nation or community. Allocating responsibility and finding equitable ways to ameliorate the problems will be highly conten- tious and conflictual and may affect patterns of international conflict. It will be important to consider a nation's contribution to global environmental degradation, its vulnerability, and its ability to bear the burdens of amelioration. There are strong claims that the burden should be shared, and the willingness of the world's nations to meet in Brazil in 1992 and consider a framework treaty for climate change is probably the best evidence of international concern. But it must be kept in mind that this event will be a beginning to addressing the problem, not a total solution.

Figure IV.2 shows a framework for equity analyses of global change. In working toward the development of an international regime to solve climate change problems, Professor Kasperson noted that it will be important to approach the equity issue without arbitrary assumptions and to allow for both moral and scientific arguments, recognizing that neither the global system nor the production of scientific information is neutral.

Ata Qureshi addressed a broad spectrum of problems, placing particular emphasis on the impact of climate changes on Third World nations and their concerns regarding this issue. In general, most of the less developed countries believe that the developed countries are the cause of the problem and that therefore it is up to the West to find solutions. Economic development is of greater cuncern to less developed countries than are greenhouse gas emissions.

Dr. Qureshi went on to enumerate the profound effect of greenhouse gas emissions on the Third World, and he pressed his view that it is important to educate government officials in these countries about the problems because they control the funds that can be made available to ameliorate them. The Climate Research Institute has addressed this task by organizing a number of conferences for the edification of government leaders and policymakers.

There are three main sources of greenhouse gas emissions worldwide: industry, automobiles, and deforestation. Climate change, however, will affect many areas: sea level, forestry, natural ecosystems, the infrastructure (especially in coastal areas), agriculture, water resources, and human health. Since a number of these problems were addressed 


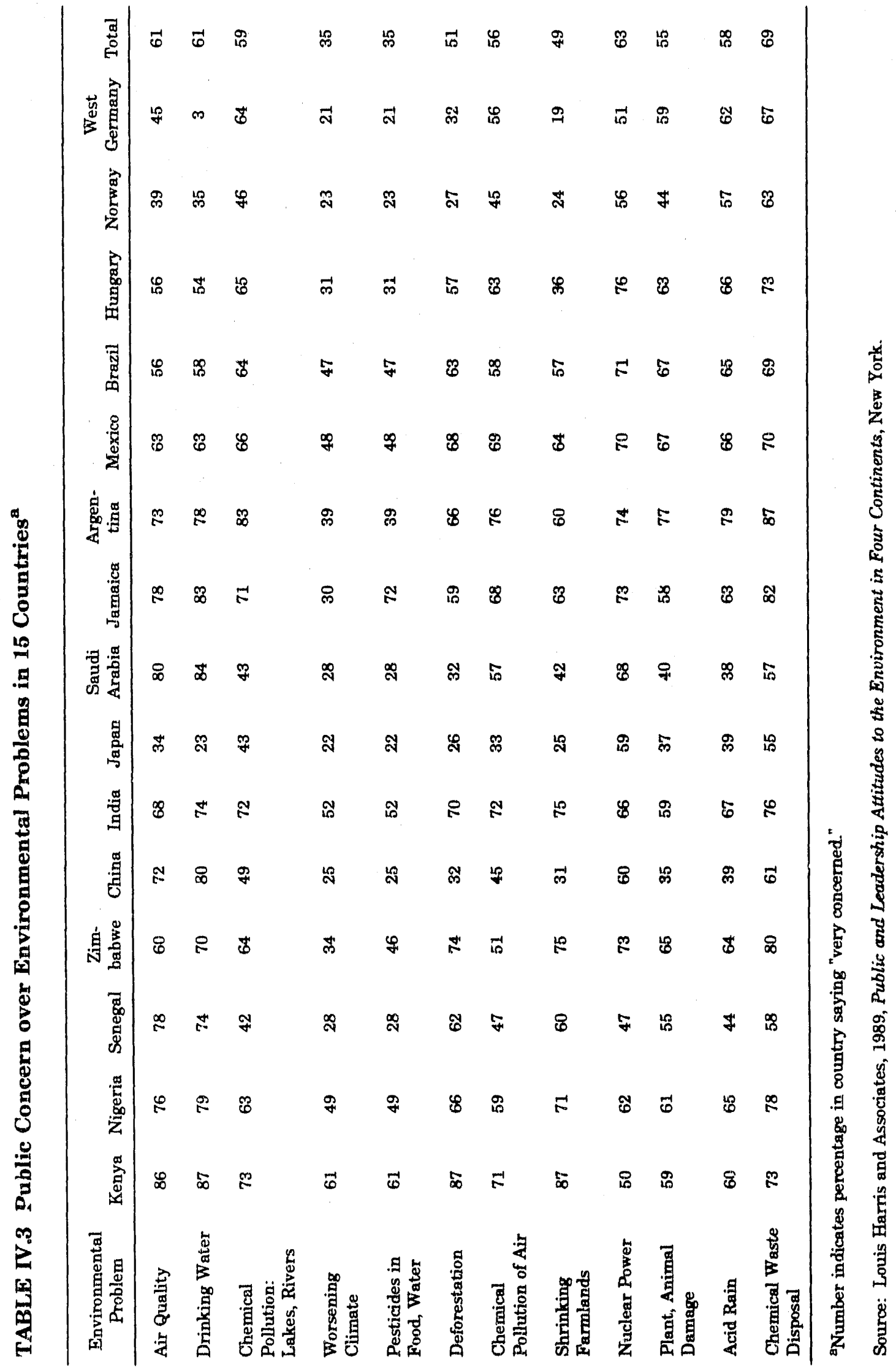




\section{TABLE IV.4 Responses to Poll on Energy Sources}

Which one of these energy sources should the U.S. rely on most for its increased energy needs in the next ten years?

$\begin{array}{ll}\text { Nuclear } & 40 \% \\ \text { Oil } & 25 \% \\ \text { Coal } & 22 \% \\ \text { Other } & 5 \%\end{array}$

Do you favor or oppose building more nuclear power plants in this country?

$\begin{array}{ll}\text { Oppose strongly } & 32 \% \\ \text { Oppose somewhat } & 20 \% \\ \text { Favor somewhat } & 22 \% \\ \text { Favor strongly } & 18 \%\end{array}$

${ }^{a}$ From a telephone poll of 1,000 American adults taken for Time/CNN on April 10, 1991, by Yankelovich Clancy Shulman. Sampling error is plus or minus $3 \%$. "Not sures" were omitted.

by previous speakers, Dr. Qureshi turned his attention to deforestation.

Deforestation is most severe in Brazil, Indonesia, and Zaire, where trees are cut for use as fuel and either cut or burned to clear land for agriculture. The irony of the latter case is that often the cleared land is not amenable to agriculture, and in hilly areas, heavy rain can deplete the soil. Deforestation in the Himalayas affects the Bay of Bengal, creating problems for the island nations and for Bangladesh. In Central America, the loss of forest cover leads to flooding and loss of topsoil. Although reforestation has begun in many areas, replacing a large tree with a small sprout is not an equal trade. In addition, size is not the only factor that determines how much $\mathrm{CO}_{2}$ a tree can absorb. Deforestation also takes place in developed countries, especially the United States. However, in the United States, the large industries responsible for cutting trees tend to replace them because it is in their own interest to do so.

\section{TABLE IV.5 Different Views of Responsibility}

1. A country is responsible for current concentrations of greenhouse gases proportional to its current emissions of greenhouse gases (World Resources Institute 1990).

2. There will be no winners from climate change in the long run.

3. In the long run, those who are responsible (for climate change) will be the winners (Klaus Meyer-Abich, Germany).

4. By shifting the onus onto the developing world, the World Research Institute whitewashes the role and responsibility of the west in destroying "our common future" (Argawal and Narian, Centre for Science and Environment).

5. Responsibility should be allocated by using indices that reflect an expectation that nations should pay back the "natural debt" in the same proportion that it was borrowed (Kirk Smith, East-West Center).

Turning to activities designed to involve all the world's nations in ameliorating the effects of clinate change, Dr. Qureshi described the work of the Intergovernmental Panel on Climate Change (IPCC), which has member nations from all regions of the world. It is supported by the World Meteorological Organization (WMO) and the United Nations Environment Programme (UNEP). Three working groups - science, impacts, and response strategies - assess problems and recommend policies. The chairpersons of these groups are from the United Kingdom, the Soviet Union, and the United States, respectively. Briefings on climate change are held for ministers and policymakers in various countries, with presentations being given in the host country's language. The participants are ministers from a variety of relevant areas who would not typically meet together. These briefings were initiated in 1990 and will continue through 1991 in 
TABLE IV.6 Growth of Fossil Fuel Use by Developed and Developing Countries, 1875-2025

\begin{tabular}{|c|c|c|c|}
\hline \multirow{2}{*}{$\begin{array}{l}\text { Country } \\
\text { and Fuel }\end{array}$} & \multicolumn{3}{|c|}{$\begin{array}{l}\text { Fossil Fuel Consumption } \\
\left(10^{18} \text { Joules }\right)\end{array}$} \\
\hline & 1975 & 2000 & 2025 \\
\hline \multicolumn{4}{|l|}{ Developed } \\
\hline Coal & 37.55 & 76.98 & 77.27 \\
\hline Oil & 60.33 & 86.37 & 80.73 \\
\hline Gas & 63.76 & 72.87 & 109.13 \\
\hline Total & 161.64 & 236.22 & .267 .13 \\
\hline \multicolumn{4}{|c|}{ Developing } \\
\hline Coal & $21.55^{\prime}$ & 47.17 & 104.85 \\
\hline Oil & 19.36 & 44.38 & 84.35 \\
\hline Gas & 4.58 & 13.98 & 51.16 \\
\hline \multirow[t]{2}{*}{ Total } & 45.49 & 105.53 & 240.36 \\
\hline & $\begin{array}{c}1975-2025 \\
\text { Increase } \\
(\%)\end{array}$ & $\begin{array}{c}\text { Average } \\
\text { Annual } \\
\text { Increase } \\
(\%)\end{array}$ & \\
\hline \multicolumn{4}{|l|}{ Developed } \\
\hline Coal & 10.5 & 2.12 & \\
\hline Oil & 33.8 & 0.68 & \\
\hline Gas & 71.2 & 1.42 & \\
\hline Total & 65.3 & 1.31 & \\
\hline \multicolumn{4}{|c|}{ Developing } \\
\hline Coal & 386.5 & 7.73 & \\
\hline Oil & 335.7 & 6.71 & \\
\hline Gas & 1017.0 & 20.34 & \\
\hline Total & 428.4 & 8.57 & \\
\hline
\end{tabular}

Source: Edmonds-Reilly Model, Reference Case, 1990.

collaboration with the Climate Research Institute. Dr. Qureshi stressed the importance of educating government policymakers as well as researchers and agricultural workers, since researchers need ministry approval to operate, and since nothing will be done unless policymakers understand the problems.
TABLE IV.7 Per Capita Greenhouse Index: 50 Countries with the Highest Per Capita Greenhouse Gas Net Emissions, 1987

\begin{tabular}{|c|c|c|}
\hline Country & Kank & $\begin{array}{l}\text { Motric 'Tons } \\
\text { por Caplta }\end{array}$ \\
\hline Lao Peoplo's Dom Rop & 1 & 10.0 \\
\hline Qatar & 2 & 8.8 \\
\hline United Arab Emirates & 3 & 5.8 \\
\hline Buhrain & 4 & 4.9 \\
\hline Canada & 5 & 4.5 \\
\hline Luxembourg & 6 & 4.3 \\
\hline Arazill & 7 & 4.3 \\
\hline Côte d'lvoiro & 8 & 4.2 \\
\hline United Ecates & $\mathfrak{g}$ & 4.2 \\
\hline Kuwait & 10 & 4.1 \\
\hline Australia & 11 & 3.9 \\
\hline German Dem Rep & 12 & 8.7 \\
\hline Oman & 13 & 3.5 \\
\hline Saudi Arabia & 14 & 3.3 \\
\hline Now Zealand & 15 & 3.2 \\
\hline Netherlands & 16 & 2.9 \\
\hline Denmark & 17 & 2.8 \\
\hline Costa Rica & 18 & 2.8 \\
\hline Singapore & 19 & 2.7 \\
\hline United Kingdom & 20 & 2.7 \\
\hline Germany, Fed Rep & 21 & 2.7 \\
\hline Finland & 22 & 2.6 \\
\hline Iroland & 23 & 2.5 \\
\hline Belgium & 24 & 2.5 \\
\hline U.S.S.R & 25 & 2.5 \\
\hline Switzerland & 26 & 2.4 \\
\hline Nicaragua & 27 & 2.4 \\
\hline Colombia & 28 & 2.3 \\
\hline Trinidad and Tobago & 29 & 2.3 \\
\hline France & 30 & 2.2 \\
\hline Austria & 31 & 2.2 \\
\hline Czechoslovakia & 82 & 2.1 \\
\hline Israel & 38 & 2.1 \\
\hline Ecuador & 34 & 2.1 \\
\hline Italy & 35 & 2.1 \\
\hline Norway & 36 & 2.1 \\
\hline Greece & 37 & 2.1 \\
\hline Poland & 38 & 2.0 \\
\hline Maynmar & 39 & 2.0 \\
\hline Bulgaria & 40 & 1.9 \\
\hline Spain & 41 & 1.9 \\
\hline Japan & 42 & 1.8 \\
\hline lceland & 43 & 1.8 \\
\hline Liberia & 44 & 1.7 \\
\hline Portugal & 45 & 1.7 \\
\hline Gweden & 46 & 1.7 \\
\hline Guinoa-Bissau & 47 & 1,6 \\
\hline Malaysia & 48 & 1.6 \\
\hline Cameroon & 49 & 1.6 \\
\hline Venezuela & 50 & 1.5 \\
\hline
\end{tabular}

Source: World Resources Institute calculation. 
Section IV

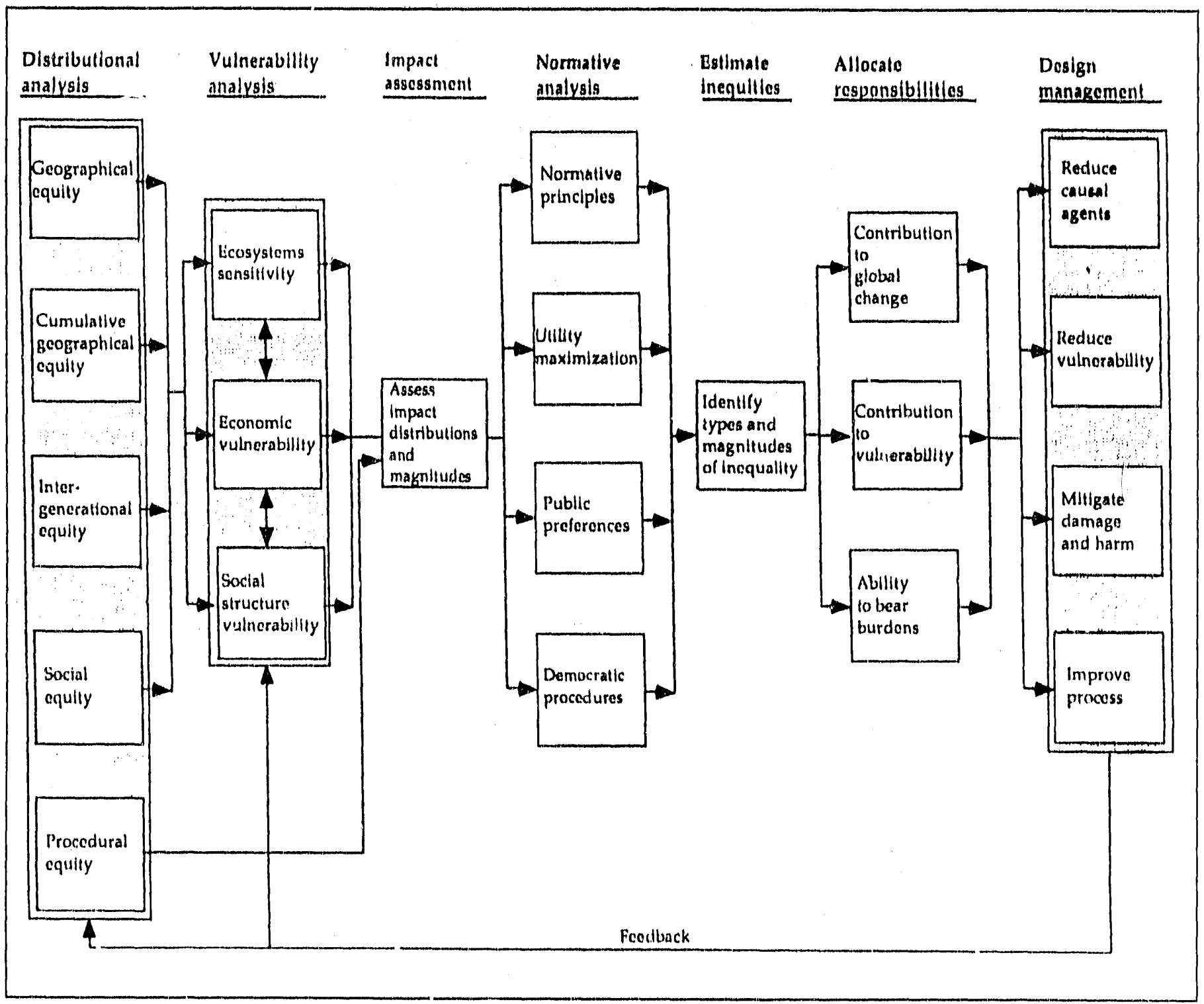

FIGURE IV.2 Framework for Equity Analyses of Global Change (Source: R. Kasperson and K. Dow, 1991, Development and Geographical Equity in Global and Environmental Change, Evaluation Review, Vol. 15, p. 152, Feb.) 


\section{Section V \\ Security Implications of Global Warming}

Security studies have traditionally addressed the causes of war, the formation of alliances, and the rise to power of different states. International eoonomists have focused on international agreemonts, shifts in leadership, and the extraction of wealth from powerful states by weak states. Prompted by international events such as the oil embargo, the discovery of the hole in the ozone layer, and the Chernobyl nuclear reactor accident, social scientists have broadened the definition of security to include the security of energy supplies and security from environmental threats. Five participants addressed the implications of global warming for security: Harold Jacolson, University of Michigan; Elizabeth Kirk, American Association for the Advancement of Science; Marvin Soroos, North Carolina State University; Matthias Finger, University of Syracuse; and David Streets, Argonne National Laboratory. Three speakers (Jacobson, Kirk, and Streets) addressed the security implications of global warming formally, utilizing a fairly broad definition of security. Soroos and Fingor presirted comments that enriched the discussion.

Harold Jacobson, in opening the discussion, argued that climate changes will not lead to armed conflict because greater international cooperation will be necessary to solve the problems caused by rising temperatures. There is no doubt that emissions of greenhouse gases will continue to increase; what is uncertain is the rate of increase. Ultimately, the Third World will be responsible for most of the increase because of its rapidly increasing population. It will also be most hurt by the onsequences of warming because its economies are more fragile and less able to respond to stress. Since the scientific knowledge that can be brought to bear to alleviate the problems is in the developed world, it is not likely that the Third World will initiate a war. Thus, we find more factors favorable to international cooperation than to conflict.

A social science model of climate change, equivalent to the general circulation model, would assist us in thinking about the relationships among the various factors contributing to glcbal warming. The following equations, in which GGE is greenhouse gas emissions, $\mathrm{C}$ is country, and em is emissions per capita, are a start on such a model.

$$
\begin{aligned}
\mathrm{GGE}= & \mathrm{C}_{1} \mathrm{GGE}+\mathrm{C}_{2} \mathrm{GGE}+\mathrm{C}_{3} \mathrm{GGE}+\mathrm{C}_{\mathrm{n}} \mathrm{GGE} \\
\mathrm{CGGE}= & \text { people } \times \mathrm{CO}_{2} \mathrm{em}+\text { people } \times \mathrm{NO}_{2} \mathrm{em} \\
& + \text { people } \times \mathrm{CH}_{4} \mathrm{em}, \text { etc. }
\end{aligned}
$$

The GGE in any year in the future will depend on the rate of chr ige of emissions and the number of years beyond the present. We do not know how the rate of emission of each gas will vary, but we do know population growth expectations, and that is ? very large number. Hence, predictions for the rise in emissions take on a very pessimistic note.

The world must leurn how to reduce the increase in greenhouse gas emissions while maintaining economic growth, because most nations would be very aissatisfied with a world that did not allow for Third World growth. On the basis of data we currently have, it seems certain that we can expect an increase in global temperature and precipitation and a rise in sea level. These effects will bring changes in economic activity that will probably lead to migration. However, it is not likely that immigration will be a direct cause of armed conflict. It might be an indirect source of armed conflict, because the higher proportion of agricultural workers in Third World countries and the lower resilience of their economies are causes of political instability. Another factor for instability that was mentioned was a strengthening of the U.S.S.R. and a greater reliance on nuclear power. This, in turn, could lead to nuclear proliferation and an increase in Third World instability.

Despite these concerns, Mr. Jacobson affirmed his belief that finding ways to address global warming will lead to greater international cooperation. That UNCED has been able to organize several conferences on these issues and that nations would even consider signing a treaty on this 
problem are positive signs of the desire for international cooperation. An additional beneficial spillover of global warming is that it can lead to unore science in policy-making.

David Streets addressed the consequences of climate change that could threaten global security in a portion of his presentation. While he did not argue that these threats would lead to armed conflict, he did draw attention to their destabilizing qualities. The threats were divided into four categories.

1. Shift in the balance of power in the developed world. An increase in temperature in the corn. and wheat-growing areas of the United States will result in a decrease in the production of these grains. Since a major portion of U.S. exports consists of agricultural products, this represents a potential loss of economic power. On the other hand, the U.S.S.R. is expected to increase its crop production, because the increase in temperature and precipitation will improve the climate for growing crops there. In addition, a temperature increase will cause the retreat of the permafrost area, which has the potential for increasing resource exploitation. Both of these factors could make the U.S.S.R. richer and more powerful.

2. Instability in the developing world. The predicted sea level rise, the widening socioeconomic gap, and the fact that the climate of many developing nations makes farming marginal are sources of potential conflict. The sea level rise in river delta areas, for example, could cause a loss of up to $20 \%$ of currently arable land. Global precipitation is predicted to rise, and contamination of water and soil by salt intrusion will add to the problem. The expected increase in tropical storm activity will stress the same areas. All of these factors can lead to an increase in environmental refugees. These problems will be exacerbated in the disadvantaged countries, because their limited economic resources and weak infrastructure leave them little capacity to deal with the stresses caused by climate change. Furthermore, they are not well-represented in international decision. making bodies.
3. Energy security. The changing dimensions of energy use as the temperature rises will put additional pressure on fuel use, which for the near term, means fossil fuel use. If the world turns to an increased use of nuclear power, nuclear proliferation may increase. An increase in average temperature is expected to increase the U.S. need for oil because of the greater amount of energy needed for cooling. While the energy needs in the East, central Great Lakes states, California, and Colorado will not change (less fuel for heating in winter will be balanced by the need for more energy for cooling in summer), the South will have up to a $15 \%$ greater need for cooling, and many northern states will experience an increase in their need for cooling that is $10 \%$ more than the decrease in their need for heating in winter. Because the United States imports half of its oil, it will be very vulnerable to changes in oil's price and available supply.

Sweden is often cited as an example of a nation with a high standard of living and a diverse and efficient energy system. Therefore, it is interesting to compute how much the world's worst emitters would have to reduce their per capita production of $\mathrm{CO}_{2}$ if the developing world were allowed to come to a reasonable standard of living with a fuel efficiency similar to that of Sweden. Under these circumstances, the United States would have to reduce its rate of $\mathrm{CO}_{2}$ emissions by $50 \%$, the U.S.S.R. by $30 \%$, and China by $200 \%$. For the world as a whole, there would have to be a threefold reduction in per capita emissions (see Table IV.7).

4. Rights and responsibilities. Disputes over who is responsible for the problem and who should contribute to its solution are also potential sources of international conflict. An international regime designed to ameliorate the consequences of climate change would have to (1) acknowledge international responsibility for the problem, (2) allow the developing countries to improve, (3) include plans by which developed nations would agree to limit their growth, and (4) provide mechanisms for the resolution of disputes and intervention in the internal affairs of many nations. 


\section{Security Implications}

Elizabeth Kirk spoke briefly about some of the security aspects of climate chenge. In the sense of its classical or political definition, national security is the maintrinance of the political system and the safety of the population via national sovereignty or the integrity of borders. Since a rise in $\mathrm{CO}_{2}$ emissions and in global temperature will not result in the violation of borders or a nation's sovereignty by military force, it is possible to argue that climate change will not affect security. However, the secondary effects of climate change rise in sea level, massive migrations, and decrease in food production - may influence political stability and the safety of a nation's citizens, especially with regard to the social and economic costs of prevention or mitigation of the effects. Thus, more recent definitions (Table V.1) view environmental depletion and other problems that threaten the quality of life as threats to security.

Marvin Soroos offered a definition of security that incorporates some of Dr. Kirk's concerns, which suggest that we are secure to the extent that we can expect to continue to enjoy what we value. Since all nations' values are not the same, the definition of security will vary from country to country. Although Professor Soroos believes that environmental concerns should be incorporated into security issues, he drew attention to some dangers in this position. Environmental security is inherently a defensive value, so perhaps it would be more advantageous to think about the world in a more creative way, directing our thoughts to the invention of new ways of living rather than trying to save the present system. Since the Third World views environmental security as being of more concern to the developed world and since the Third World places greater value on economic growth, this might be a more productive approach. Moreover, thinking of the environment as a security issue may lead to self-serving unilateral policies rather than international cooperation, as has been the case with military security.

Matthias Finger, referring to the Army War College Manual, pointed out that the greatest threat: to security may come from the impact of the army on the environment. He suggessted that the idea of environmental security draws upon the notion of collective security, which developed in response to

the nuclear +": eat. Historically, the idea of security is attached to the nation-state. Therefore, the use of the term environmental security calls up the notion of a military defense to external threats and is probably not the best way to think about preventing the degradation of the environment. What the organizations that use the term really want to emphasize is the threat to humanity from poor environmental quality. They are concerned with humanity as a whole, but as individuals rather than as nations. Use of the term environmental security in this sense weakens the concern for the environment because it puts it into the category of everyday issues along with job security, work security, etc. Therefore, Professor Finger urged that we get away from Cold War thinking and visualize environmental security as being in the best interests of all people. In this approach, western developed nations are not secure unless less developed nations are also secure.

\section{TABLE V.1 Definitions of Security}

\section{Old definition (Elizabeth Kirk)} (1977)

Richard Ullman, Princetion (1983)

John Firor (1991)
Security means the mainte. nance of the sovereignty of a country - the integrity of its borders, the safety of its populations, and the mainte. nance of its political system.

Environmental degradation is a threat to security.

Threats to security are all acts and events that greatly diminish the quality of life and substantially reduce policy options open to government.

A desirable state of national security is one in which human-induced changes in the environment do not produce tensions, instabilities, or other impacts that threaten the freedom or prosperity of people in the nation. 


\section{Section VI}

\section{Discussion}

This section presents issues raised during vigorous and varied discussions that followed some of the formal presentations. It contains answers to questions and comments made by participants in response to other statements. No effort has been made to identify the speakers except where their remarks were extensive, referred to their research results, or opinions were stated in response to a question.

\section{Improving the Models}

It was pointed out that while oceanographers may be able to generate better models of the oceans than climatologists, there are less data about ocean temperatures because they are not as well monitored as the atmosphere. Some ocean phenomena, such as eddies, cannot be modeled as yet; nevertheless; they carry a lot of energy and cortribute to the distribution and absorption of $\mathrm{CO}_{2}$.

There was considerable discussion of how the results of new atmospheric research will affect our understanding of climate change and the accuracy of predictions. Many people believe that more information about the behavior of clouds and oceans will reduce the uncertainty of the models, but not everyone agreed. It was pointed out that research might also uncover new problems that could increase the uncertainty. It was also noted that some information that already exists, such as that on the hydrologic cycle, has not been used in the models as much as it should be.

A discussion developed around the connection between the effort to obtain more information about cloud formation and behavior and improvement in weather forecasting. Sorne believe that the increased amount of data worldwide will lead to better forecasting. Others think that information already available on the effects of local features such as mountains and lakes is not used to capacity, and improvement in its use will lead to more accurate weatiner predictions.
Responding to a question, Dr. Sisterson stated that the increase in data resulting from the CHAMMP Program would reduce the uncertainty in the predicted temperature increase to less than the overall predicted change in about ten years. He thought it unlikely that this much reduction in the temperature uncertainiy would occur in only five years. He pointed out that the increase in local data will assist policymakers who are concerned about potential crisis situations such as major storms in their areas.

\section{The Value of Models}

Despite the imprecision of models, both natural and social scientists argued that models serve a useful function because they bring together diverse processes and can give a sharper picture of the factors that will influence the climate. A model can be tested, and if it agrees with existing data, it increases our confidence in its predictive ability.

Furthermore, models help us to focus attention on the processes that are taking place and can thus increase our understanding of the phenomena even when they cannot provide accurate predictions. Individual measurements give information for the conditions at the instant the data were recorded. An enormous amount of data may have to be searched to discover patterns that can illuminate processes. Furthermore, models can be tested to see if they mimic existing data. If this is the case, we can be fairly certain that the important processes have been captured. The focus on processes can also serve as a guide to new research that may be needed.

The coupling of models (e.g., using results obtained by improvements in the general circulation model to feed into the economic model) can advance our ability to choose effective policies. For example, the use of models in the study of acid rain forced chemists to realize that they needed the help of ocologists, cloud physicists, and motennolngists to 


\section{Discussion}

fully understand the problern. In a similar way, interdisciplinary meetings serve to bring out the shortcomings in the various models and suggest directions for their improvement.

Given the divergence of the models, how can they be used to develop public policy? A comparison of the difference in the predicted temperature change when no action is taken to reduce $\mathrm{CO}_{2}$ emissions versus the expected change produced by an effort to reduce the increase in $\mathrm{CO}_{2}$ emissions shows that in the short term, it won't matter very mach if no action is taken. This suggests that we have time to continue ongoing research efforts before implementing strong policy changes. Nevertheless, a recent National Academy of Sciences study recommended the implementation of conservation measures and the development of adaptive strategies to mitigate the consequences of climate change. Many people are in favor of conservation measures because they can also alleviate the problems caused by pollution and acid rain and provide for better management of natural resources.

As natural and social scientists work to make their research accessible to policymakers, it is important to help the latter understand that even if all the models agreed, there would still be no absolute answers nor any unique solution to the problem of global warming. Furthermore, although climate change will not be experienced to the same degree in all areas, the fact that the world is economically interdependent means that all nations will be affected. This fact should be kept in mind when U.S. policy measures to counteract the greenhouse effect are being developed.

\section{Climate Change and Conflict}

Since all areas of the globe will not experience the same climate change, the issue of winners and losers and its potential for conflict was discussed extensively. Concern was expressed that putting emphasis on the idea of winners and losers will create conflicts that may never end. The possibility was raised of addressing the issue as a philosophical idea or in an economic context, without identifying specific countries or regions as winners or losers. This issue was not resolved.
Within the Soviet Union are areas in the south that could become arid at the same time that crops in northern areas would profit from higher temperatures. It has been suggested that higher temperatures would make it easier to extract the mineral resources of Siberia. However, nany Soviet scientists fear that the melting of the permafrost layers could cause severe problems that have never been studied and that might make it more difficult to exploit the mineral resources known to exist there. The historical evidence makes it difficult to accept the idea of the Soviet Union becoming a major agricuitural power. Hence, many doubted that the Soviet Union would achieve a high level of economic power as a result of global warming.

On the issue of climate change and conflict, it was noted that there are already conflicts between nations over water resources. Nations that use river water for drinking and irrigation are often in conflict with nations upstream because of the pollution and the reduction in the water's flow rate caused by this use. Examples cited were Egypt and the Sudan and Israel and Jordan. Climate change would cause additional stress to nations dealing with these problerns.

There was some speculation that nations might not accept the limitations on sovereignty needed to control emissions. Others noted that these limitations are already part of the world order (e.g., in the GATT agreements and the CFC Treaty).

The question of the formation of blocs of winners and losers or developed nations and less developed nations that could prevent international action to reduce greenhouse gas emissions was discussed at length. It was generally thought that bringing more scientists into the policy-making process would be helpful. However, it was noted that scientists from developing countries who participate in meetings on climate problems are often chosen by their governments and are expected to present their government's point of view. Concern was expressed that if the negotiations on handling climate change were seen as a zero sum distribution, nothing will be accomplished.

Dr. Qureshi addressed some of these issues. He noted that scientists in the developing countries 
were working to convince government ministers not to adopt a zero sum distribution view of global warming. He believes it would be beneficial to raise funds to permit scientists from developing countries to participate in international meetings privately. In that way, all who are interested can attend these meetings, not just those who are given funds by their government and expected to support its views. As for preventing the formation of a negotiating block of less developed countries, he called attention to the role of the "behind the scenes" discussions that take place at all large international gatherings. While these are very time-consuming activities and require much care and consideration, they usually get results, and he is hopeful that they can help to forestall problems in this case.

\section{Sociopolitical Impacts}

The discussion focused largely on educating mass publics, keeping public attention focused on long-term issues, understanding how the lay public absorbs scientific information, and improving the presentation of it. The need for more reporters with science backgrounds as well as the importance of providing training for reporters now at work was seen as crucial. Increasing attention is being given to developing an understanding of risk assessment on the part of the press. It was suggested that universities with journalism departments could play a major role in this effort. Another example is the University of Chicago Benton Fellowship program, which brings journalists to the university for a year of study in a subject of their own choosing, as a way of educating practicing journalists.

How saturation of public interest and creation of public fear affect human response to issues involving risk and uncertainty were seen as questions that raeded further research. For example, in the United States, there is a significant fear of nuclear power that has remained quite stable over time. It can be mobilized by particular events and has prevented the construction of new plants for over ten years, but little is known about swings in public opinion.

How the public absorbs scientific information is not well understood. In the case of greenhouse gas emissions, there is some evicience that people incorporate their knowledge of this subject into their understanding of previous similar problems (in this case, the destruction of the ozone layer). But this, too, is a subject that needs study.

Since climate change has been on the scientific agenda for twenty years, the possibility that there is a cyclic nature to public concern was suggested. While it is known that policy problems often are characterized by oscillation between scientific and moral issues, the idea of a cyclic pattern has not been studied, and polls going back to 1.980 do not show it. Matthias Finger disagreed with this view, stating that he has daia for polls going back to 1970 that do show a cyclic effect. His studies suggest that people become sensitized by one catastrophic event (for example, Chernobyl), and when another critical event occurs, they tend to overreact. This behavior makes it difficult to mobilize public opinion in an organized and rational fashion.

The fact that the issues have moral as well as scientific dimensions was stressed repeatedly. The creation of a climate for the open discussion of both aspects of the issues is a major need. In a situation of uncertainty or of insufficient scientific data, politicians will readily resort to NIMTOF (not in my term of office). Education of the public and the politicians was deemed essential to provide the base of support for the difficult government decisions that lie ahead.

Other equity issues that were mentioned included: Does the future have a political constituency? Who pays now and benefits now versus who pays now and benefits later? How should the future be discounted? If we waste our future, will we be affected or will all the effect fall on our children? Although the problems are international in scope, will the benefits of emissions reduction cross national boundaries?

\section{The UNCED Meeting}

The 1992 United Nations Conference on the Environment and Development received considerable attention. It was stressed that scientists from both developed and developing countries should participate as scientists, not as government representatives. Emphasis was placed on the importance of bringing the scientists from developing and developed nations into contact. 


\section{Discussion}

Another means of fostering these contacts might be to provide an arena outside the government in which they can meet to analyze and discuss scientific information. The Pugwash Conferences (named for the location of the first such meeting in Nova Scotia) are an example of such an arena. Held at irregular intervals during the Cold War, they provided an informal channel of unofficial communication between U.S. and Soviet scientists during a period when official government communication was often minimal and fraught with tension.

Changes in the international urder (e.g., in the way governments make policy decisions) will affect the focus of discussions in Brazil. The importance of ensuring that high-level policymakers attend the meeting was stressed. However, when even ideology is not stable over time (as changes such as the recent ones in eastern Europe and the Soviet Union show), how will the appropriate policymakers be known? Even when governments change on a smaller scale, the education of policymakers has to start all over again.

These issues led to a discussion of nongovernment organizations (NGOs) and whether they can play a constructive role in meetings on environmental issues or whether their presence is counterproductive because of their identity as advocate groups. If they can be recognized as groups that have tracked various problems over time and are thus able to provide useful information, they have valuable contributions to make. One important role is that they can bring both stability and expertise to large international groups. In addition, they often have important data to present (as evidenced by the role played by Greenpeace in the Antarctic Treaty effort). NGOs can call meetings that governments do not want to hold and gather participants through social pressure. Whatever UNCED decides about the participation of NGOs, they will certainly be present in Brazil, although they may not sit at the table. A strongly stated final reminder was that NGOs are frequently advocate groups and should not be equated with the scientific community.

\section{Miscellaneous Items}

It was noted that our concerns are focused on the worst-case scenario - namely, the greatest predicted temperature change - although the temperature change that actually occurs may not fall within the predicted range. However, what we can be sure of is that we are looking at changes that are greater than any humanity has experienced, and we should certainly be concerned with the human dimensions of adapting to or coping with these changes.

It is an interesting paradox that most of the modeling of climate change is being done in the United States (five of six models are American and only one is European), yet the Europeans are pushing for controls on emissions while the United States is procrastinating on controls and recommending further study.

While it may be true that policymakers are looking for specific advice, not scientific information, we must recognize that it is difficult to find certainty in a complex, nonlinear world, especially one that is interconnected. Politicians and policymakers will have to understand this, too, and our effort should be directed toward ways to become better informed about complex systems. On the other hand, often countries do not use the information they already have, particularly with regard to preparing for extreme events (e.g., severe storms and volcanic eruptions).

In response to a question about the attainment of population stabilization by raising the standard of living, it was noted that economic motives and the level of the standard of living are important, but the empowerment of women is absolutely necessary for changing population growth. This led to a query about the technical and economic changes that would have to accompany population growth if the standard of living were to be maintained, but no solutions to this problem were offered. However, Professor Kasperson described a research effort that examines the relationship between population growth and environment by region, especially situations in which the relationship is moving to a critical stage. The study is examining adaptations that occur in response to resource and environ. mental depletion, the means of stabilizing or moving away from critical situations, and areas in which populations are living in a sustained relationship with the environment, as in some sparsely populated areas. 
Section VI

Attention was drawn to the fact that past temperature changes do not correlate with periods of high human welfare. For exarnple, the best match between food supply and population historically was between 1200 and 1600 , a period of declining temperature. 


\section{Section VII \\ Conference Program}

MAY 8, 1991

5:30 - 7:30 Reception and Dinner

7:30 - 9:30 SESSTON I

Welcome

Ioel Snow, Associate Vice President for Argonne National Laboratory, University of Chicago

Predicting Climate Change: Certainties and Uncertainties

Tom Donahue, University of Michigan

MAY 9, 1991

9:00 - 11:00 SESSION II

Physical, Economic, Social and Security Consequences of Climate Change

Charles Lipson, University of Chicago (Chair)

Richard Kosobud, University of Illinois at Chicago

Vernon Ruttan., University of Minnesota

Roser Kasperson, Clark University

11:00 - 11:20 Coffee Break

11:20 - 12:30 SESSION II (continued)

Discussion

$12: 30-2: 00 \quad$ Lunch

$2: 00-3: 30 \quad$ SESSION III

Climate Change and Energy Production and Consumption

David Streets, Argonne National Laboratory (Chair)

David South, Argonne National Laboratory

Ata Qureshi, Climate Research Institute

3:30 - 3:50 Coffee Break

3:50 - 5:30 SESSION III (continued)

Discussion

6:00 - 8:30 Dinner 
Section VII

MAY 10, 1991

9:00 - 10:20 SESSION IV

Current Research Projects

Robert Ayres, Carnegie Mellon University

John Firor, National Center for Atmospheric Research

Douglas Sisterson, Argonne National Laboratory

10:20 - 10:40 Coffee Break

10:40 - 12:10 SESSION IV (continued)

Laboratory Tours: Integral Fast Reactor and Superconductivity

12:15 $\cdot 1: 30 \quad$ Lunch

1:30 - 3:30 SESSION V

Wrap-up Discussion and Formulation of New Interdisciplinary Research Agendas Harold Jacobson, University of Michigan (Chair) 


\section{Section VIII \\ Conference Participants}

Professor Robert U. Ayres

Carnegie Mellon University

Ms. Uma Balakrishnan

University of Notre Dame

Professor R. Stephen Berry

University of Chicago

Dr. Peter Breke

BDM International, Inc.

Professor John Clark

University of Kansas

Mr. Jim Clem

University of Michigan

Dr. Rob Coppock

National Research Council

Professor Craig David

Ohio State University

Professor Thomas Donahue

University of Michigan

Ms. Elizabeth Economy

University of Michigan

Professor Matthias Finger

Syracuse University

Dr. John W. Firor

National Center for Atmospheric

Research

Professor Norton Ginsburg

University of Chicago

Dr. Don Hanson

Argonne National Laboratory

Professor Harold Jacobson

University of Michigan
Professor Roger Kasperson

Clark University

Dr. Elizabeth Kirk

American Association for the

Advancement of Science

Professor Charles Kolstad

University of Illinois

Professor Richard Kosobud

University of Illinois at Chicago

Mr. Danny Lam

Indiana University

Mr. Myungsuk Lee

Indiana University

Professor James Lindsay

University of Iowa

Professor Charles Lipson

University of Chicago

Ms. Annette Matheny

University of Illinois

Professor James K. Mitchell

Rutgers University

Professor Elinor Ostrom

Indiana University

Dr. Ata Qureshi

Climate Research Institute

Dr. Marian Rice

American Academy of Arts and

Sciences

Professor Vernon Ruttan

University of Minnesota 
Dr. Douglas Sisterson

Argonne National Laboratory

Dr. Joel Snow

University of Chicago

Professor Marvin Soroos

North Carolina State University

Mr. David South

Argonne National Laboratory
Professor James Sterba

University of Notre Dame

Dr, David Streets

Argonne National Laboratory

Mr. Steven Vavrick

University of Illinois

Mr. Edward Weber

University of Wisconsin 


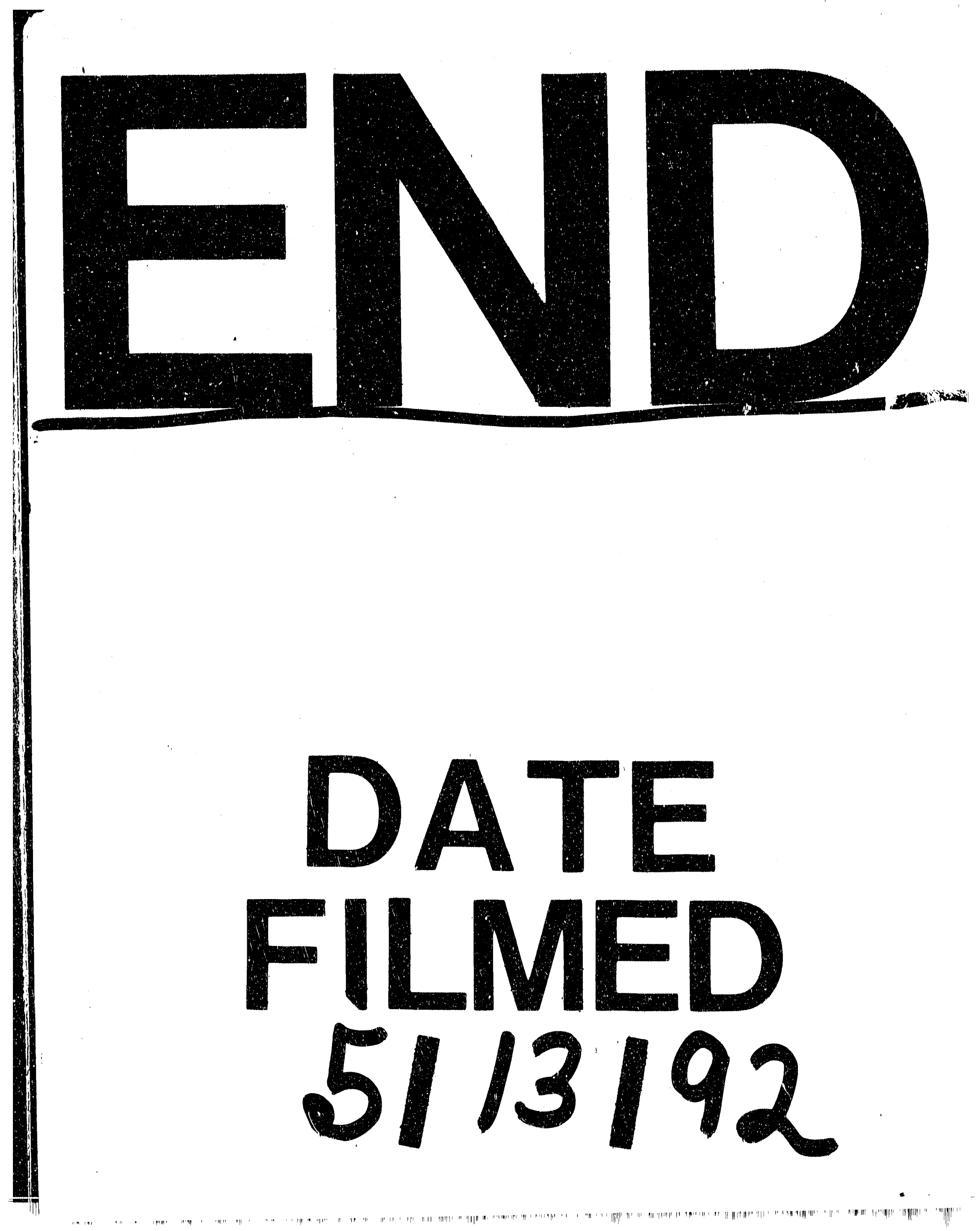


